\title{
COMPUTATION OF THIN-WALLED CROSS-SECTION RESISTANCE TO LOCAL BUCKLING WITH THE USE OF THE CRITICAL PLATE METHOD
}

\section{A. SZYCHOWSKI ${ }^{1}$}

Thin-walled bars currently applied in metal construction engineering belong to a group of members, the crosssection resistance of which is affected by the phenomena of local or distortional stability loss. This results from the fact that the cross-section of such a bar consists of slender-plate elements. The study presents the method of calculating the resistance of the cross-section susceptible to local buckling which is based on the loss of stability of the weakest plate (wall). The "Critical Plate" (CP) was identified by comparing critical stress in cross-section component plates under a given stress condition. Then, the $\mathrm{CP}$ showing the lowest critical stress was modelled, depending on boundary conditions, as an internal or cantilever element elastically restrained in the restraining plate (RP). Longitudinal stress distribution was accounted for by means of a constant, linear or non-linear (acc. the second degree parabola) function. For the critical buckling stress, as calculated above, the local critical resistance of the cross-section was determined, which sets a limit on the validity of the Vlasov theory. In order to determine the design ultimate resistance of the cross-section, the effective width theory was applied, while taking into consideration the assumptions specified in the study. The application of the Critical Plate Method (CPM) was presented in the examples. Analytical calculation results were compared with selected experimental findings. It was demonstrated that taking into consideration the $\mathrm{CP}$ elastic restraint and longitudinal stress variation results in a more accurate representation of thin-walled element behaviour in the engineering computational model.

Keywords: thin-walled members, elastic restraint, "critical plate", local buckling, longitudinal stress variation, local critical resistance, design ultimate resistance of cross-section

\footnotetext{
' PhD., Eng., Kielce University of Technology, Faculty of Civil Engineering and Architecture, Al. 1000-lecia PP 7 , 25-314 Kielce, Poland, e-mail: aszychow@tu.kielce.pl.
} 


\section{INTRODUCTION}

Metal thin-walled members with Class 4 cross-sections are susceptible to different modes of instability, namely local, distortional, and overall buckling. Each of these modes is characterised by a different form of displacement and different half-wavelengths of buckling. The critical length of local buckling is of the order of cross-sectional dimensions $\left(l_{c r}{ }^{L} \approx b\right)$, the length of distortional buckling is, on average, one order of magnitude higher (e.g. $l_{c r}{ }^{D} \approx 7-11 b$ ), and the length of overall (flexural, flexural-torsional or lateral-torsional) buckling is of the order of the member span, or of the distance between restraints $\left(l_{c r}{ }^{O} \approx l\right)$. The cross section of thin-walled members of this class is usually composed of slender-plate elements (thin walls) which can be directly modelled as plates.

According to the currently binding Eurocode 3 [50], the phenomena of local and distortional buckling, despite differences in buckling lengths, are accounted for by means of reduction in crosssection resistance. The method of effective width (for local buckling) and reduced thickness (for distortional buckling) is used. On the other hand, the overall stability loss is addressed by a reduction factor calculated on the basis of the non-dimensional slenderness of the member. To estimate effective widths, the local buckling critical stress is determined for individual plates on the assumption that they are simply supported. Furthermore, the influence of possible longitudinal stress variation is disregarded. The effective width of the flange, on the side of potential stiffening of the free edge, is also indirectly used to estimate distortional buckling critical stress. On this basis, the effective thickness of the stiffener is determined. Such a computational model was adopted in the code [50]. When both phenomena have been accounted for, the effective cross-section (composed of appropriate effective widths and reduced thicknesses) is obtained. It is used to compute appropriate characteristics of the cross-section $\left(A_{\text {eff }}, W_{\text {eff }}\right)$.

In view of the above, it is a matter of crucial importance to correctly determine the local buckling critical stress. It provides a basis for determining: 1) effective widths of individual plates, 2) distortional buckling critical stress (the substitute cross-section of the stiffener consists of appropriate effective widths), and 3) the overall non-dimensional slenderness of the member.

This study presents the method for determining the local buckling critical stress and the design ultimate resistance of thin-walled cross-section, in which a more accurate computational model is employed. This means taking into account the effect of the mutual elastic restraint of component plates and the influence of longitudinal stress variation. 


\section{CONCEPTS OF TAKING THE EFFECT OF LOCAL BUCKLING INTO}

\section{ACCOUNT}

The concept of separating plate elements, assuming they are simply supported on longitudinal edges of connections, was adopted in the codes $[49,50,51]$ on the design of thin-walled members with Class 4 cross-section. The critical stress is determined individually for plates separated in this manner. In this approach, the "local" critical resistance of the thin-walled section, determined from the condition of local buckling, depends on the critical stress of the weakest plate. After relative slenderness of individual plates (thin walls) has been determined, appropriate effective widths are determined, which are then "combined" to form the effective cross-section of the thin-walled member. Such an approach is different from that applied to distortional buckling [50]. In the computational model of the latter phenomenon, it is assumed that rotational spring stiffeners are found at the junction of the edge-stiffened flange and the web. In section 5.3 (Table 5.2.), the code [50] allows modelling thin walls with rotational and translational spring stiffeners, yet solutions concerning local buckling are not given at all. In this respect, the code [50] recommends the design engineer should rely on the computational model acc. code [51], which is equivalent to the adoption of the concept of separating simply supported plates.

Theoretical investigations into whole cross-sections, e.g.[1,8,9,10,19], computations with the Finite Element Method (FEM), e.g.[6,47], or Finite Strip Method (FSM), e.g.[20,28], and experimental investigations, e.g.[2,11,15,21,25,26], indicate that the influence of adjacent plates occurs. In an actual thin-walled cross-section, e.g. a cold-formed one, the phenomenon of elastic restraint of adjacent plates is found in local buckling. This issue has been raised by many researchers.

A hypothesis can be formulated that the weakest plate is decisive for the local buckling of the crosssection under different load states. This plate is elastically restrained against rotation at the stronger, neighbouring plate. Additionally, elastic restraint stiffeners are found on the longitudinal edges of the plate connection. Consequently, in thin-walled members made from flat thin walls, the weakest plate, termed the "critical plate" (CP), is elastically restrained against rotation in the stronger, restraining plate, labelled as RP. Buckled CP causes RP deflection because in their rigid connection on the common edge, the condition of continuity of displacements (rotation angles) and forces (moments) is maintained. As a result, an impression is produced that all cross-section plates buckle at the same time, but $\mathrm{CP}$ deflections in moderate post-buckling are, on average, an order of magnitude greater than forced deflections of RP [15,31]. 
It is obvious that in some sections, under specified load conditions, neighbouring plate elements do not provide elastic restraint to each other because they buckle at almost the same time. The box section in axial compression for $h=b$ and $t_{f}=t_{w}$, or in bending about the major axis for $h=2.44 b$ and $t_{f}=t_{w}$ provides an example of such a situation. Further on in this study, cross-sections of this type are termed "zero cross-sections", and only in those cases, the code assumption on simple support of component plates on connection edges is satisfied. In the majority of cases, however, a $\mathrm{CP}$ can be identified in the thin-walled member, which is decisive for the local buckling of this cross-section under a specific stress state.

Technical literature offers a very large number of solutions to different problems of stability of thin plates loaded in their planes. The solutions were obtained using different methods, e.g. the energy method. In the majority of cases, those solutions concern plates that are under axial or eccentric compression or shear, at constant stress intensity along the length, e.g. [1,43]. A number of problems related to the stability of a segment of thin-walled bar composed of plates and separated by the buckling nodal lines have also been solved $[1,8,9,19,24]$. An extensive survey of results was presented in study [48].

However, the studies on plate stability, which also account for the conditions of the edge elastic restraint and longitudinal stress variation are not readily available. In a few papers, the plate elastic restraint was considered, but that was done for constant stress intensity along the plate length [1]. Alternatively, longitudinal stress variation was taken into account but that concerned simply supported plates $[1,13,14,45,46]$. The issues of simultaneous occurrence of elastic restraint of the plate edge and longitudinal stress variation have been in the scope of interest of the author of this study. These activities have produced a series of papers devoted to those problems $[31,32,33,34$, 35, 36, 37, 38, 39, 40, 41, 42]. The results obtained make it possible to develop more accurate computational methods, in which the actual behaviour of thin-walled members under load is rendered more realistically.

Computer methods (FEM, FSM) are also successfully applied to determine the critical load on the thin-walled member. In those methods, the critical load and the mode of the cross-section buckling are obtained. However, it is not unambiguously indicated which plate is decisive for local buckling. The results thus produced can be applied, e.g. to the direct resistance determination with the use of the Direct Strength Method (DSM) [29,30,52]. Study [25], however, demonstrated that DSM could not be a universal method in thin-walled member design. For instance, the method does not account for the disadvantageous effect of the shift of the effective cross-section centre of gravity when 
compared with its position for the gross cross-section. That refers to, e.g. monosymmetric and nonsymmetric cross-sections under compression. Conversely, in the effective width method, it is necessary to determine the critical stress for individual elements because the determination of the slenderness of "stronger plates" on the basis of the critical stress calculated for the whole crosssection (in which "weaker plates" are decisive) leads to cross-section resistance underestimation. Additionally, using FEM, design engineers have to model a given problem individually every time, taking into account many aspects of the actual thin-walled member behaviour. The issues that need to be addressed include, among others, a proper selection of finite elements, the manner of mesh generation, the way the load is applied, and appropriate modelling of actual support conditions. Surely, FEM nonlinear analysis can be applied to investigate thin-walled member behaviour in a post-buckling state, and in failure. However, developing approximate methods (the ones worked out by hand, or in the form of spreadsheets) of the resistance assessment allows, among others, production of preliminary design and a simple validation of computations made with the use of FEM or FSM.

In the monograph [16], it was shown that an increase in stress in the thin-walled cross-section above the critical stress of the weakest element $(\mathrm{CP})$ results in a quick growth of the element deflection. Also, at first, the stronger element (RP) shows a slow deflection increment, and it behaves like a plate with initial deflection, operating in the pre-buckling state. Only when the load reaches the value, at which stress in RP is close to critical for this plate, a quick increase in deflection also occurs. At that moment, the whole cross-section already operates in the full post-buckling state. In that case, buckling stress that is applied to estimate the effective width for CP can be determined at the assumption that $\mathrm{CP}$ is elastically restrained. As regards the estimation of the effective width in $\mathrm{RP}$, the assumption concerns RP simple support (hinge) on the edge of connection to CP. Such an approach simplifies computations, and from the engineering standpoint, is sufficiently accurate [16]. In studies $[3,4]$, Chudzikiewicz presented an original theory of "deformability buckling" of axially compressed thin-walled bar, for which a half-wavelength of buckling is of the order of the member length. Cross-sections were divided into simple and complex ones. A cross-section is simple if its deformation, due to, e.g. local buckling, does not directly cause displacements of the points in the plane of a given plate (thin wall), but merely a deflection in the direction normal to this plate [3]. If buckling results in displacements in the plane of the plate, such a cross-section is considered to be complex [4]. Examples of simple and complex cross-sections, important from the technical standpoint, are presented in Fig.1 

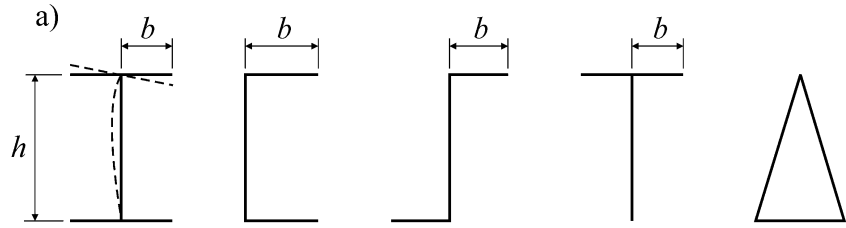

b)
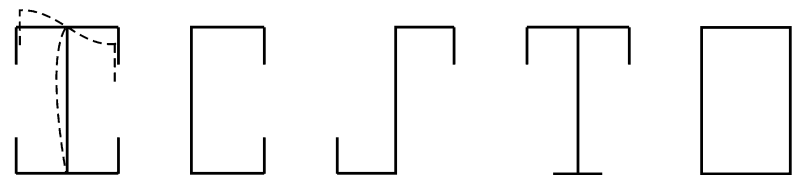

Fig. 1. Examples of simple (a) and complex (b) cross-sections acc. definition [3,4]

The division into simple and complex cross-sections, acc. Fig.1, was followed in this study to simplify computational procedures. Conversely, "deformability buckling" as presented in studies $[3,4]$ was not analysed.

In studies [31,32], a segment of a thin-walled bar was defined as a member section separated by transverse stiffenings (e.g. ribs, diaphragms or supports) which ensure rigid cross-section contour in place of their location. The segment length is determined by the spacing of stiffeners, regardless of spontaneously produced nodal lines of buckling. The minimal number of stiffeners is two. In this case, the thin-walled member consists of one segment.

In study [32], a distinction was made between thin-walled bars with a "rigid cross-section contour", satisfying the assumptions of the Vlasov theory [44] for the whole elastic range and thin-walled bars with a "flexible cross-section contour", which are affected by local or distortional stability loss. Additionally, the so-called "local critical bimoment" $\left(B_{c r}{ }^{L}\right)$ was defined, which was determined from the condition of local buckling of the thin-walled bar segment under warping torsion.

By analogy to $B_{c r}{ }^{L}$, in this study, the notions of "local critical axial force" $\left(N_{c r}{ }^{L}\right)$ and "local critical bending moment" $\left(M_{c r}{ }^{L}\right)$ are introduced. These are determined from the condition of local buckling of the bar segment under simple load states $(N$ or $M)$. "Local" buckling resistance of the crosssection (measured by external load) can be estimated from formula (2.1) for axial compression, and from formula (2.2) for bending.

$$
N_{c r}^{L}=\sigma_{c r} A / \gamma_{M 0}
$$

$$
M_{c r}^{L}=\sigma_{c r} W_{e l, s} / \gamma_{M 0}
$$


where: $\sigma_{c r}$ - local buckling critical stress in simple load states ( $N$ or $\left.M\right), A$ - gross area of cross-section, $W_{e l, s}$ - gross elastic section modulus, $\gamma_{M 0}$ - partial factor of cross-sections resistance.

"Local" critical resistances $\left(B_{c r}{ }^{L}, N_{c r}{ }^{L}, M_{c r}{ }^{L}\right)$ impose a limitation on the theory of thin-walled bars by Vlasov [44], restricting it to the pre-buckling range of behaviour of thin-walled bar segment with flexible cross-section contour.

In monograph [12], the cross-section resistance from the condition of yield of the most compressed edge of the effective cross-section, which is regarded as a conservative estimation of the limit loadcarrying capacity, was distinguished from the cross-section resistance in the failure stage. The latter is determined for the mechanism of plastic hinge, and considered to be non-conservative estimation of the limit load-carrying capacity.

To design reliable metal building structures, engineers focus on design resistance, which is determined from the condition of yield of the most compressed edge of the effective cross-section. That means conservative estimation of the limit load-carrying capacity acc. [12]. By contrast, resistance in the failure stage is used when designing, e.g. mechanical energy absorbers [12].

To differentiate between local critical resistance and resistance from the condition of yield of the most compressed edge of the effective cross-section, in the present study the latter is termed as the design ultimate resistance. Conversely, the resistance of thin-walled cross-section in the failure stage, which is characterised by large deformations [12], is not analysed in this study.

As regards the analysis of local buckling of a thin-walled member, technical literature does not provide simplified methods for the determination of the degree of CP elastic restraint in the adjacent RP. The aim of the present study is to provide a method for determining buckling stress and computing the design ultimate resistance for a thin-walled cross-section. The method is termed the Critical Plate Method (CPM), and it accounts for the conditions of CP elastic restraint in RP (or RPs) and the effect of longitudinal stress variation.

\section{THE CRITICAL PLATE METHOD (CPM)}

\subsection{ASSUMPTIONS}

Due to boundary conditions on longitudinal edges that occur in practice, CPs were divided into two basic types: I - internal plates (Fig.2a,b) and II - cantilever plates (Fig.2c). Additionally, internal 
plates were categorised into two subtypes (Ia and Ib). In this study, it was assumed that for the single edge fold stiffener, having the same thickness as the flange (Fig.2b.), the advantageous effect of elastic restraint against rotation about this edge is modest [1], and from the technical standpoint, can be neglected.

a)

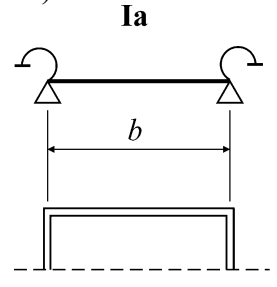

b)

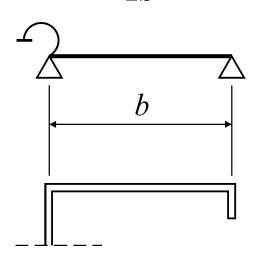

c)

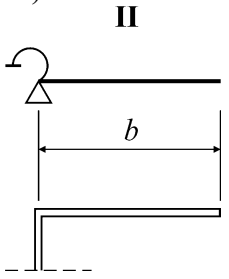

Fig. 2. Types of "critical plates"

It was assumed that: 1) $\mathrm{CP}$ behaves as an internal plate elastically restrained against rotation (Ia, Ib), or a cantilever plate (II), 2) CP connection to RP (for instance to the web) is rigid, which means that on the longitudinal edge of their connection, the conditions of continuity of displacements (angles of rotation) and forces (bending moments) are fulfilled, 3) transverse edges of the plates (CP and RP) on the bar segment ends are simply supported.

In practice, when making assumption 2 , it is necessary to make certain that the continuity mentioned above occurs in connections of the cross-section component plates. The impact of the manufacturing technology of thin-walled section on reciprocal elastic restraint of individual elements of the plate should be considered. In welded sections (e.g. box sections), a disadvantageous effect of residual welding stress can be manifested. As shown in study [27], the strongest effect of that kind occurs in axially compressed cross-sections. A similar effect is also found in cold-formed sections that are additionally welded [7]. In such cases, the degree of reduction in the local buckling critical stress and in the ultimate resistance of the cross-section can be accounted for as it was done in studies [7,17,27]. However, a major impact of the residual stress, related to the section bending, on the reduction in reciprocal elastic restraint of the walls was not observed [7]. Instead, a beneficial effect was attributed to an increase in the index of fixity due to the dimensions of rounded corners resulting from the bending process. Yet, study [7] demonstrated that this effect is not revealed until large bending radii are found, and that is reduced due to the compressive stress in the corners. For example, in the elastic range, for plate slenderness $\lambda_{p} \approx 47$, 
and at compressive stress $\sigma_{c}=100 \mathrm{MPa}$, the advantageous effect occurs only above $r / t \geq 15$, and for $\lambda_{p} \approx 67$ and $\sigma_{c}=100 \mathrm{MPa}-$ above $r / t \geq 22$ [7]). In view of the above, in technically important cases, the advantageous effect of the roundness magnitude can be disregarded because modern manufacturing methods of cold-formed members allow obtaining satisfactory cross-section geometry already at $r / t=2 \div 5$. Consequently, in this range of $r / t$ ratios, the advantageous effect of material strengthening is found in the section corners, which is due to cold work [50].

Thus, in technical computations, it can be assumed that continuity of displacements and forces on the edge of CP connection to RP is found in cold-formed and hot-rolled sections, and also in full penetration butt welds section, or those with double fillet welds (e.g. in I-section, at the flange/web connection). However, further investigations are still required for the problem of the elastic restraint of thin walls jointed by a single fillet weld, e.g. in box sections.

As stated earlier, thin-walled cross-sections built from thin plates are divided into: 1) simple crosssections and 2) complex cross-sections acc. [3, 4] (Fig.1). It is possible to claim that simple crosssections can locally buckle acc. Hancock [5] and undergo "deformability" buckling [3], whereas complex cross-sections can be subjected to local, distortional [18], and also "deformability" buckling [4].

From the standpoint above, when conducting the analysis of exclusively local buckling, crosssections showing behaviour similar to that of simple cross-sections can also include typical box sections, and those open sections, the flanges of which have a relatively narrow single edge fold stiffener. Such a stiffener constitutes the flange support, with spring stiffness $K$ [50], preventing its deflection, yet it does not act as a restraint against rotation [42]. That results from low torsional stiffness of the single edge fold stiffener having the thickness equal to that of the flange. This stiffness is additionally reduced by compressive stress. According to [50], the analysis of local buckling of the stiffened flange can be made on the assumption that spring stiffness of the stiffener $K=\infty$. Additionally, it is assumed that, in this case, the stiffener width is sufficient to not make the element buckle locally. To meet this requirement, it is enough that the thin wall thickness should be greater than:

$$
t>\frac{c}{326} \sqrt{\frac{f_{y b}}{k_{\sigma}}}
$$

where: $c$ - width of the single edge fold stiffener, $f_{y b}-$ basic yield strength, $k_{\sigma}-$ buckling coefficient acc. [50] As regards typical box sections, it is local buckling that is primarily decisive for their deformation. 
Although in study [4] those were categorised as complex cross-sections (Fig.1b), "deformability" buckling occurs at much higher loads on box cross-section relative to its local critical resistance.

In this study, the cross-sections mentioned above, whose behaviour is similar to that of simple cross-sections were termed semi-complex. Examples of such cross-sections and the proposed way of computational modelling of these are shown in Fig. 3.

a)

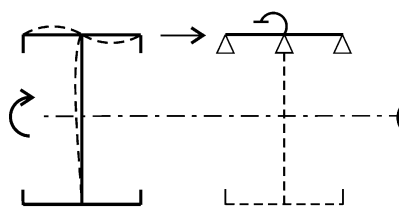

b)

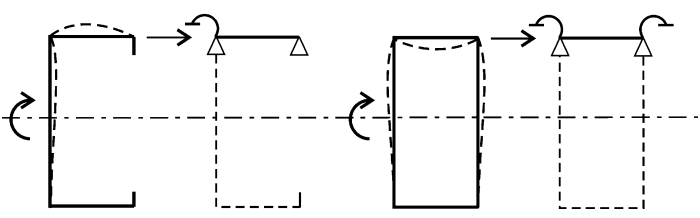

Fig. 3. Examples of semi-complex cross-sections and their computational modelling

\subsection{DEFINITION OF THE CRITICAL PLATE}

The term "critical plate" (CP) was chosen for this element of thin-walled section, a given stress state of which is characterised by the lowest critical stress, while taking into account reciprocal elastic restraint of component plates on the longitudinal lines of their connection to a cross-section.

The issue is which thin wall of the cross-section acts as $\mathrm{CP}$ at a given stress distribution. It can be resolved by means of the analysis of the local buckling critical stress for separate plates, elastically restrained against rotation on longitudinal edges. In this case, the weakest plate (at a given stress distribution) is characterised by the lowest local buckling critical stress. In the generalized geometric framework of the thin-walled cross-section, the condition for $\mathrm{CP}$ can be written as follows:

$$
\sigma_{c r, s}=\min \left\{\sigma_{c r, i}\right\}
$$

where: $\sigma_{c r, s}-$ critical stress for $\mathrm{CP}$ when taking elastic restraint into account, $\sigma_{c r, i}$ - critical stress for the remaining i-th plates, under the same assumption.

For simple and semi-complex cross-sections, the condition for CP is simplified to the following:

$$
\sigma_{c r, s}^{o}=\min \left\{\sigma_{c r, i}^{o}\right\}
$$


where: $\sigma_{c r, s}^{o}$ - critical stress for $\mathrm{CP}$ on the assumption of CP simple support on one or both longitudinal edges (Fig.2), $\sigma_{c r, i}^{o}$ - critical stress for the remaining i-th plates, under the same assumption.

Condition (3.3) simplifies computations, because $\sigma_{c r, i}^{o}$ can be determined from a widely known formula:

$$
\sigma_{c r, i}^{o}=k_{i}^{o} \sigma_{E, i}
$$

where: $k_{i}^{o}$ - basic plate buckling coefficient for separate, simply supported i-th plate at given load distribution (e.g. acc [51]), $\sigma_{E, i}$ - Euler stress for the i-th plate acc. formula:

$$
\sigma_{E, i}=\frac{\pi^{2} E}{12\left(1-v^{2}\right)}\left(\frac{t_{i}}{b_{i}}\right)^{2}
$$

where for $E=210000 \mathrm{~N} / \mathrm{mm}^{2}$ and $v=0.3$, it can be approximately assumed that $\sigma_{E, i}=190000\left(t_{i} / b_{i}\right)^{2}[51]$.

After CP has been identified in the thin-walled cross-section, it is assumed CP is elastically restrained against rotation in the adjacent RP (Fig.2bc), or with two-sided restraint in the restraining plates (Fig.2a and Fig.3). That means the critical stress for CP is higher than for the assumption of CP simple support. If the adjacent plates (walls) are under the same critical stress, or the differences in the critical stress between those plates are lower than approx. $15 \%$, their reciprocal elastic restraint does not occur, or is very weak. When that is the case, computations of cross-section resistance can be performed on the basis of the method involving the separation of the pinsupported plates, e.g. acc. [51].

For particular geometric ratios of complex cross-sections shown in Fig.1b, or for cross-sections having even more complex geometry, the condition acc. formula (3.3) is not sufficient. In that case, it is necessary to rely on a more general condition acc. formula (3.2). The manner of identifying CP in complex cross-sections on the basis of condition (3.2) will be discussed in a separate study.

\subsection{BOUNDARY CONDITIONS OF THE CRITICAL PLATE}

The degree of the elastic restraint of the longitudinal edge of $\mathrm{CP}$, which constitutes the internal plate Ia (for $y_{s}=0$ and $y_{s}=b_{s}$ ), plate $\mathrm{Ib}$ (for $y_{s}=0$ ) or cantilever plate II (for $y_{s}=0$ ) was described by means of the index of fixity $\kappa$, which has the form: 


$$
\kappa=1 /\left(1+2 D_{s} / b_{s} C_{\theta}\right)
$$

where: $C_{\theta}$ - rotational spring stiffness equal to the bending moment created by rotation by a unit angle $\left(C_{\theta}=M / \theta\right), b_{s}$ - width of the plate subjected to buckling $(\mathrm{CP}), D_{s}$ - plate flexural rigidity acc. formula:

$$
D_{s}=\frac{E t_{s}^{3}}{12\left(1-v^{2}\right)}
$$

where for $E=210000 \mathrm{~N} / \mathrm{mm}^{2}$ and $v=0.3$, it can be approximately assumed that $D_{s}=19200 t_{s}{ }^{3}$.

The index of fixity $\kappa(3.6)$ ranges from $\kappa=0$, for simple support, to $\kappa=1$, for complete restraint.

On the basis of theoretical e.g. $[1,8,9,19,32]$ and experimental e.g. $[2,11,15,21,25,26]$ investigations, it was stated the rotational spring stiffness $\left(C_{\theta}\right)$ of the CP supported edge is most affected by the plate (RP) that is directly adjacent to $\mathrm{CP}$, on the assumption that the plates are rigidly connected along the edge they share. The rotational spring stiffness resulting from the action of RP can be determined from formula:

$$
C_{\theta}=\frac{c_{j} \eta_{i} D_{r}}{b_{r}}\left(1-\frac{\sigma_{c r, s}}{\sigma_{c r, r}}\right)
$$

where: $c_{j}$ - parameter of the geometric arrangement of component plates joined on the $\mathrm{j}$-th edge, $\eta_{i}-$ coefficient dependent on load distribution, geometry and support conditions of RP, $b_{r}$ - width of RP, $D_{r}=$ $19200 t_{r}{ }^{3}$ - plate flexural rigidity of RP, $\sigma_{c r, s}$ - sought critical stress for CP, $\sigma_{c r, r}$ - critical stress for RP treated as a simply supported plate, determined for the half-wavelength equal to the buckling length $\left(l_{c r}\right)$ of $\mathrm{CP}$.

It should be noted that in formula (3.8), the expression in parenthesis accounts, in an approximate manner, for the disadvantageous effect of compressive stress in RP [18].

In simple (Fig.1a) and semi-complex (Fig.3) cross-sections, parameter $c_{j}$ takes the following values: $c_{j}=1$, if one RP stabilizes one CP on one edge (Fig.4a), $c_{j}=1 / 2$, if one RP stabilizes two CPs on one edge (Fig.4b), and $c_{j}=2$, if two RPs stabilize one CP on one common edge (Fig.4c).

Thus computations are iterative in nature because to determine rotational spring stiffness $C_{\theta}(3.8)$, it is necessary to have buckling stress for $\mathrm{CP}$, which depends on $\kappa$ acc. (3.6), and consequently, on $C_{\theta}$. For simple and semi-complex cross-sections, the process is fast convergent, and generally two or three iterations are sufficient. 
a)

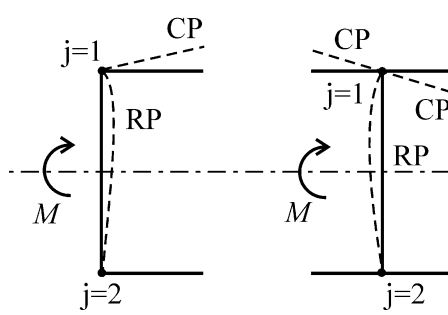

c)

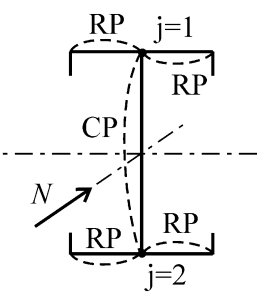

Fig. 4. Cross-section division into critical (CP) and restraining (RP) plates

\subsection{DEFINITION OF "ZERO" CROSS-SECTIONS}

Cross-sections, in which thin walls in compression (e.g. flange and web) at a given stress distribution lose stability simultaneously, are termed "zero" cross-sections. In such a case, reciprocal elastic restraint of compressed component plates does not occur.

In simple or semi-complex "zero" cross-sections (Fig.5a,b), the following can be differentiated: flanges with width $b$ and thickness $t_{f}$ and webs with height $h$ and thickness $t_{w}$. The dimensions of the thin-walled cross-section given above were assumed for the so-called midlines of component plates. "Zero" cross-sections were defined on the basis of their geometry and the manner of loading. These referred to the web height. The height of "zero" cross-section $h_{0}$ can be determined from formula:

$$
h_{0}=\delta \frac{t_{w} b}{t_{f}}
$$

where:

$$
\delta=\sqrt{k_{w}^{o} / k_{f}^{o}}
$$

$k_{w}{ }^{o}, k_{f}^{o}$ - plate buckling coefficients for web and flange, respectively, on assumption of their simple support on the connection line.

If in the thin-walled cross-section $h<h_{0}$, compressed flange is decisive for local buckling (the flange is CP). If $h>h_{0}$, it is the web, compressed or bent in its plane, that decides (the web is CP), and if $h=h_{0}$, both walls (e.g. flange and web) are critical plates and elastic restraint does not occur for them. In such a case, the cross-section resistance can be determined on the basis of the concept of the separation of plates, simply supported on the longitudinal edges of connection. The values of 
coefficient $\delta$ for some types of simple and semi-complex cross-sections in basic stress states are presented in Fig.5 (compressive stress was hatched).

a)
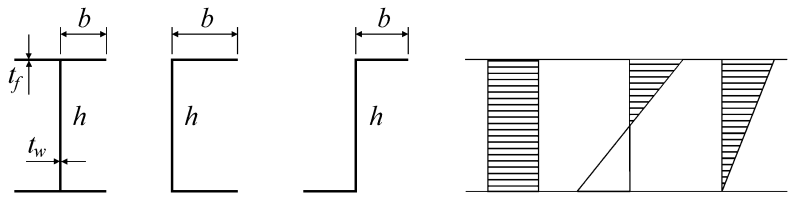

b)
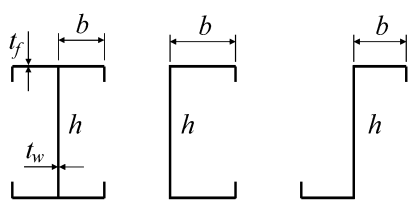

$\delta=3.05$
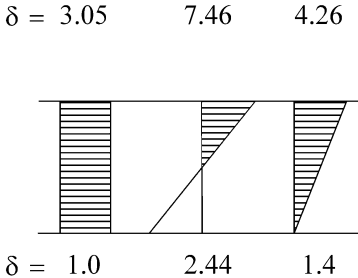

Fig. 5. Examples of "zero" cross-sections and selected values of coefficient $\delta$

\subsection{TYPES OF RESTRAINING PLATES}

Depending on boundary conditions and load state on longitudinal connection edges, restraining plates can be divided into three types $(i=1,2,3)$ shown in Fig.6.

a) $i=1$

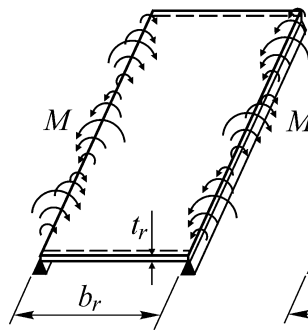

b) $i=2$

c) $i=3$

Fig. 6. Types of restraining plates with width of $b_{r}$ and thickness of $t_{r}$ acc. [10]

For the sake of local buckling analysis, coefficients $\eta_{i}$ in formula (3.8) can be adopted acc. [10]. In this study, the formulas for coefficients of rotational spring stiffness of the edge of the plate subjected to buckling were derived on the basis of the differential equation for the restraining plate bending. The formulas were reliant on the static scheme and the manner in which the i-th restraining 
plate was loaded (Fig.6) due to the buckling of the critical plate. Simple approximation formulas for coefficients $\eta_{i}$ were also proposed:

$$
\begin{aligned}
& \eta_{1}=\sqrt{118.8+84.6\left(\frac{b_{r}}{l_{c r}}\right)^{2}}-8.9 \\
& \eta_{2}=\sqrt{33.4+50.7\left(\frac{b_{r}}{l_{c r}}\right)^{2}}-2.78 \\
& \eta_{3}=\sqrt{0.533+44.9\left(\frac{b_{r}}{l_{c r}}\right)^{2}}-0.73
\end{aligned}
$$

where $l_{c r}$ - predicted length of CP buckling half-wave.

In study [10], however, detailed guidelines on the appropriate selection of the critical length $\left(l_{c r}\right)$ of the plate undergoing buckling were not provided. It was only suggested that for an internal plate, it is possible to assume $l_{c r}=b_{s}$, while for the cantilever plate buckling, approximately $l_{c r}=\infty$. In such a case, for different types of plates restraining (Fig.6) the critical cantilever plate, coefficients $\eta_{i}$ are: $\eta_{1}=2, \eta_{2}=3$ and $\eta_{3}=0$, respectively. The computations conducted for this study indicate that such an approach produces very conservative estimates, especially for cantilever CPs.

To determine $C_{\theta}$ acc. (3.8) and $\kappa$ acc. (3.6) in a more accurate way, it is necessary to estimate the expected buckling length $\left(l_{c r}\right)$ of CP. This is related to the assumption that for CP buckling, halfwavelength of RP deformation is approximately equal to $l_{c r}$.

For the stress distribution, which is constant along the bar segment length, spontaneously formed buckling half-waves are the same in length and amplitude. In longitudinal stress variation, buckling half-waves created along the segment length differ in length and have varied (e.g. decreasing) amplitudes [31,32,33]. Consequently, the bar segment zone, in which the maximum compressive stress occurs, is decisive for local buckling. In study [33], the "critical half-wave" was defined as the one with the highest deflections, which occurs in the area of the greatest stress. The critical halfwavelength of buckling $\left(l_{c r}\right)$ was assumed to be, as for constant stress intensity, the distance between the points of inflexion of the "trace" of the first buckling mode.

When $\kappa>0$, elastic restraint of the CP edge in RP is found, and CP buckling length is: 1) for the 
internal plate (Ia or Ib, Fig.2): $l_{c r}<b_{s}$, and 2) for the cantilever plate (II, Fig.2): $l_{c r}<4.25 b_{s}$ for the range $0.05 \leq \kappa \leq 1$, which means that $l_{c r}<<\infty$.

Approximation formulas for estimating the CP buckling length as a function of $\kappa$ for axially compressed, long plates at constant stress intensity along the length were derived by the author in the following studies [33,40,41]. These formulas can be presented as follows (Fig.2): a) for the internal plate (Ia) - formula (3.14), b) for the internal plate (Ib) - formula (3.15), c) and for the cantilever plate (II) - formula (3.16).

$$
\begin{gathered}
l_{c r}=b_{s}\left(1-0.23 \kappa+0.07 \kappa^{2}-0.17 \kappa^{3}\right) \\
l_{c r}=b_{s}\left[1-0.103\left(\kappa+\kappa^{2}\right)\right] \\
l_{c r}=b_{s}\left(\frac{2.02-0.37 \kappa}{\kappa^{0.25}}\right)
\end{gathered}
$$

Study [34] demonstrated that in typical cases of the cantilever plate (II) eccentric compression in the plane, the buckling length $\left(l_{c r}\right)$ could be also estimated from formula (3.16).

As indicated earlier, computations are iterative because to determine coefficient $\eta_{i}$, it is necessary to know the value of $l_{c r}$, which depends on index $\kappa$. In turn, $\kappa$ depends on rotational spring stiffness $C_{\theta}$, and eventually on the computed critical stress $\sigma_{c r, s}$. In computational practice, however, when an assumption on the initial value of index $\kappa$ (e.g. from the range 0.2-0.5) is made, the process is fast convergent. The accuracy that is satisfactory from the technical standpoint is obtained after only two or three iterations.

The critical stress in RP $\left(\sigma_{c r, r}\right)$ (for one half-wave of deflection), found in formula (3.8), corresponding to the buckling length $\left(l_{c r}\right)$ of CP can be estimated on the basis of $[1,18,43]$ : a) for axially compressed internal plate acc. formula (3.17), for internal plate bent in its plane acc. formula (7.8), and for axially compressed cantilever plate acc. formula (3.19):

$$
\begin{gathered}
\sigma_{c r, r}=\frac{\pi^{2} D_{r}}{t_{r} b_{r}^{2}}\left(\frac{b_{r}}{l_{c r}}+\frac{l_{c r}}{b_{r}}\right)^{2} \\
\sigma_{c r, r}=\frac{E t^{2}}{l_{c r}^{2} b_{r}^{4}}\left(11.32 l_{c r}^{4}+1.97 b_{r}^{4}+12.06 l_{c r}^{2} b_{r}^{2}\right)
\end{gathered}
$$




$$
\sigma_{c r, r}=\frac{\pi^{2} D_{r}}{t_{r} b_{r}^{2}}\left(0.425+\frac{b_{r}^{2}}{l_{c r}^{2}}\right)
$$

Such an approach allows accounting, in an approximate but technically sufficient manner, for the disadvantageous effect of compressive stress in RP. For longitudinal stress variation, the buckling length of the "critical half-wave" [33] is from a few to several percent shorter than for constant stress distribution along the bar segment. The buckling length can be determined using software described in studies $[33,40,41]$. The adoption of $l_{c r}$ acc. formulas $(3.14,3.15,3.16)$ produces the results that are sufficiently accurate from the technical standpoint. Also, that leads to slightly conservative estimates of $\sigma_{c r, s}$ for $\mathrm{CP}$, and $\sigma_{c r, r}$ for RP.

\subsection{THE CRITICAL BUCKLING STRESS}

Depending on load distribution, the elastic buckling stress for CP of the thin-walled section is determined from formula:

$$
\sigma_{c r, s}=k \sigma_{E, s}
$$

where: $k$-plate buckling coefficient, $\sigma_{E, s}$ - Euler stress for CP acc. formula (3.5).

Buckling coefficients $(k)$ for different cases of the plate (CP in this case) support and loading were presented by the author in the form of graphs in the following studies [32, 33, 34, 35, 36, 37, 38, 39, $40,41,42]$, and in the form of approximation formulas in [22, 23, 33, 40, 41]. In addition, the index of fixity $(\kappa)$ and longitudinal stress distribution were accounted for using the following functions: a) constant, b) linear and, c) non-linear acc. the second degree parabola.

\subsection{COMPUTATIONAL PROCEDURE FOR CPM}

In the Critical Plate Method, computations of the local critical resistance and the design ultimate resistance of the thin-walled cross-section are run as follows:

1) identification of $\mathrm{CP}$ : a) for simple and semi-complex cross-sections - on the basis of condition (3.3), Chapter 3.2 or Chapter 3.4 ; b) for complex cross-sections - acc. condition (3.2), Chapter 3.2. The manner of CP identification acc. condition (3.2) will be presented in a separate paper; 
2) assumption of the initial value of the index of fixity of the CP edge, e.g. $\kappa_{j=0}=0.3$;

3) estimation of the expected CP buckling length $\left(l_{c r}\right)$ acc. formulas $(3.14,3.15$ or 3.16, Chapter 3.5) depending on $\kappa$ value and plate type;

4) determination of coefficient $\eta_{i}$ on the basis of formulas $(3.11,3.12$ or 3.13$)$, depending on RP static diagram and RP loading by the CP being buckled (Fig.6.);

5) for $\kappa_{j}$ value, determination of the buckling coefficient $(k)$ from studies [22, 23, 32, 33, 34, $35,36,37,38,39,40,41,42]$, depending on the plate type and load distribution, and computation of the CP buckling stress $\sigma_{c r, s}\left(\kappa_{j}\right)$ acc. formula (3.20);

6) estimation of the critical stress $\sigma_{c r, r}$ for RP (for one half-wavelength of deflection) acc. formulas $\left(3.17,3.18\right.$ or 3.19) and expected $l_{c r}$ of CP acc. step 3);

7) determination of the rotational spring stiffness $\left(C_{\theta}\right)$ acc. formula (3.8) and the index of fixity $\left(\kappa_{j=j+1}\right)$ for the first, and the successive iteration step;

8) repetition of steps 3 ) to 7), until $\kappa_{j} \approx \kappa_{j+1}$;

9) $\sigma_{c r, s}\left(\kappa_{j+1}\right)$ acc. formula (3.20) is the sought buckling stress for CP;

10) determination of the local critical resistance of the thin-walled cross-section on the basis of CP buckling stress from formula (2.1) for axial compression, or formula (2.2) for bending;

11) determination of the design ultimate resistance of the cross-section using the effective width method, on the following assumptions: a) the relative plate slenderness should be determined for the critical stress in individual component plates, b) for $\mathrm{CP}$, the stress accounts for $\mathrm{CP}$ elastic restraint against rotation and potential longitudinal stress variation, c) for RP, it is necessary to assume simple support on the same edge, d) boundary conditions on the other edge of the internal RP generally only slightly affect the computational results (in a conservative manner, simple support can also be assumed here), e) for cantilever RP, the other edge is free (unsupported), f) the effect of the potential longitudinal stress variation in RP is marginal and can be disregarded, g) effective widths determined as above are put together into an effective cross-section, and on that basis the design ultimate resistance is determined.

The difference with respect to the classic version of the effective width method primarily lies in the following: 1) identification of the wall which functions as CP, 2) estimation of CP elastic restraint in RP, 3) computation of the buckling stress for $\mathrm{CP}$ while taking into account $\kappa$ and potential longitudinal stress variation, 4) determination of the effective widths of component plates acc. assumptions above (from step 11). 
The procedure for the determination of the local critical resistance and the design ultimate resistance of the thin-walled cross-section with the use CPM is presented in the examples in Chapter 4.

\section{COMPUTATIONAL EXAMPLES}

Examples of the CPM application to calculations of simple and semi-complex thin-walled crosssections of Class 4 are presented below. To estimate the amount of work necessary to make calculations, all examples were calculated by hand. To simplify calculations, dimensions of the midline of cross-sections were adopted due to the thin-walled nature of plate elements (Fig.2). From the technical standpoint, this manner of calculations is accurate enough if the radius $(r)$ of corner roundness is: $r<5 t$ and $r<0.1 b$ [50]. The determined local buckling critical stress was verified by FEM computations performed using the Abaqus software [6].

\section{Example 1.}

Compute the local critical resistance and the design ultimate resistance of $\mathbf{Z}$ cross-section (Fig.7a.) in axial compression. It should be noted that numbers given in parenthesis refer to formulas presented in previous chapters.
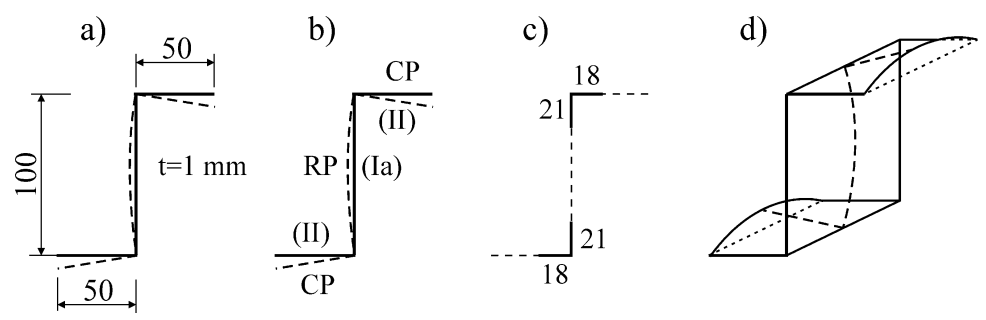

Fig. 7. a) Cross-section geometry, b) division into CPs and RP, c) effective cross-section acc. the CPM, d) mode of local buckling for a single half-wavelength

Data: S355 steel, $f_{y}=355 \mathrm{~N} / \mathrm{mm}^{2} ; E=210000 \mathrm{~N} / \mathrm{mm}^{2} ; v=0.3 ; t=1 \mathrm{~mm} ; A=200 \mathrm{~mm}^{2} ; \gamma_{M 0}=1$. Theoretical plastic resistance of the gross cross-section when local buckling is disregarded is:

$N_{p l, R d}=A f_{y} / \gamma_{M 0}=200 \cdot 355 / 1=71000 \mathrm{~N}=71 \mathrm{kN}$.

It is Class 4 cross-section $(b / t=50>14 \varepsilon ; h / t=100>42 \varepsilon)$;

Euler stress (3.5): flange $\sigma_{E f}=190000(1 / 50)^{2}=76 \mathrm{~N} / \mathrm{mm}^{2}$; web $\sigma_{E w}=190000(1 / 100)^{2}=19 \mathrm{~N} / \mathrm{mm}^{2}$. Flexural rigidity (3.7): flange, web: $D_{f}=D_{w}=19200 \cdot 1^{3}=19200 \mathrm{Nmm}$. 
Computations acc. the CPM procedure:

1) identification of CP acc. Chapter 3.2.: critical stress in simply supported component plates acc.[51] (3.4): flange $\sigma_{c r, f}^{o}=0.43 \cdot 76=32.7 \mathrm{~N} / \mathrm{mm}^{2}$; web $\sigma_{c r, w}^{o}=4 \cdot 19=76 \mathrm{~N} / \mathrm{mm}^{2} ; Z$ cross-section acc.Fig.7a. is simple (Fig.1a), hence acc. condition (3.3): $\sigma_{c r, s}^{o}=\min \{32.7 ; 76\}=32.7 \mathrm{~N} / \mathrm{mm}^{2}-$ $\mathrm{CP}$ is a flange (flanges), and RP is a web (Fig.7b.);

2) initially it was assumed that $\kappa_{0}=0.2$ (for zero step, $j=0$ );

3) estimation of the buckling length acc. (3.16): $l_{c r, 0}=50\left[(2.02-0.37 \cdot 0.2) / 0.2^{0.25}\right]=145 \mathrm{~mm}$;

4) RP is the internal plate, loaded on both edges by buckling flanges (Fig.6a. and Fig.7b), hence coefficient acc. $(3.11): \eta_{1,0}=\left[118.8+84.6(100 / 145)^{2}\right]^{1 / 2}-8.9=3.71$;

5) buckling coefficient acc. approximation formula from study [33], or acc. Table 1 from study [34]) is $k\left(\kappa_{0}=0.2\right)=0.654$; hence buckling stress for CP acc. $(3.20): \sigma_{c r, s, 0}=0.654 \cdot 76=49.7 \mathrm{~N} / \mathrm{mm}^{2}$;

6) critical stress of RP for $l_{c r, 0}$, i.e. for a single half-wave acc. (3.17): $\sigma_{c r, r 0}=3.14^{2} \cdot 19200 /\left(1 \cdot 100^{2}\right) \cdot(100 / 145+145 / 100)^{2}=86.75 \mathrm{~N} / \mathrm{mm}^{2} ;$

7) rotational spring stiffness (3.8): $C_{\theta, 0}=1 \cdot 3.71 \cdot 19200(1-49.7 / 86.75) / 100=304(\mathrm{Nmm} / \mathrm{rad}) / \mathrm{mm}$, hence the index of fixity $(3.6): \kappa=1 /[1+2 \cdot 19200 /(50 \cdot 304)]=0.284>\kappa_{0}=0.2$;

8) first iteration step $(j=1): \kappa_{1}=0.284 ; l_{c r, 1}=131 \mathrm{~mm} ; \eta_{1,1}=4.06 ; k\left(\kappa_{1}\right)=0.709 ; \sigma_{c r, s, 1}=$ $0.709 \cdot 76=53.88 \mathrm{~N} / \mathrm{mm}^{2} ; \sigma_{c r, r 1}=81.46 \mathrm{~N} / \mathrm{mm}^{2} ; C_{\theta, 1}=264(\mathrm{Nmm} / \mathrm{rad}) / \mathrm{mm} ; \kappa=0.256<\kappa_{1}=0.284 ;$ second iteration step $(j=2): \quad \kappa_{2}=0.256 ; \quad l_{c r, 2}=135 \mathrm{~mm} ; \quad \eta_{1,2}=3.95 ; \quad k\left(\kappa_{2}\right)=0.69 ; \quad \sigma_{c r, s, 2}=$ $0.69 \cdot 76=52.44 \mathrm{~N} / \mathrm{mm}^{2} ; \quad \sigma_{c r, r 2}=82.83 \mathrm{~N} / \mathrm{mm}^{2} ; \quad C_{\theta, 2}=278(\mathrm{Nmm} / \mathrm{rad}) / \mathrm{mm} ; \kappa_{2}=0.266 \approx \kappa_{1} ;$

9) eventually, buckling coefficient acc.[33]: $k\left(\kappa_{2}=0.266\right)=0.696$; buckling stress of CP is: $\sigma_{c r, s}=$ $0.696 \cdot 76=52.9 \mathrm{~N} / \mathrm{mm}^{2}$, which is greater than the stress value determined acc.[51] by: $[(52.9-32.7) / 32.7] \cdot 100 \%=\underline{61.8 \% ;}$

10) local critical resistance of the cross-section in axial compression acc. (2.1) $N_{c r}{ }^{c p}=A \sigma_{c r, s} / \gamma_{M 0}$ $=200 \cdot 52.9 / 1=\underline{10580 \mathrm{~N}}=\underline{10.58 \mathrm{kN}}$, while the local critical resistance estimated for the critical stress determined acc. [51]: $N_{c r}{ }^{E C 3}=\underline{6.54 \mathrm{kN}}$.

FEM verification with the use of ABAQUS software [6] - Fig.8:

S4R shell elements were used (four nodal ones with six degrees of freedom in a node), having the dimensions $5 \times 5 \mathrm{~mm}$ (Fig.8a), "Buckling" procedure was selected, segment length $l_{s}=400 \mathrm{~mm}$ (i.e. approx. $3 l_{c r, 2}$ acc. step 8.), boundary conditions: continuous support along the cross-section midline in the direction perpendicular to the i-th component plate (Fig.8a.).

Critical stress acc. FEM: $\sigma_{c r}{ }^{F E M}=55 \mathrm{~N} / \mathrm{mm}^{2}$.

When compared with the CPM, the difference was approx. $[(55-52.9) / 52.9] \cdot 100 \%=+4 \%$. 


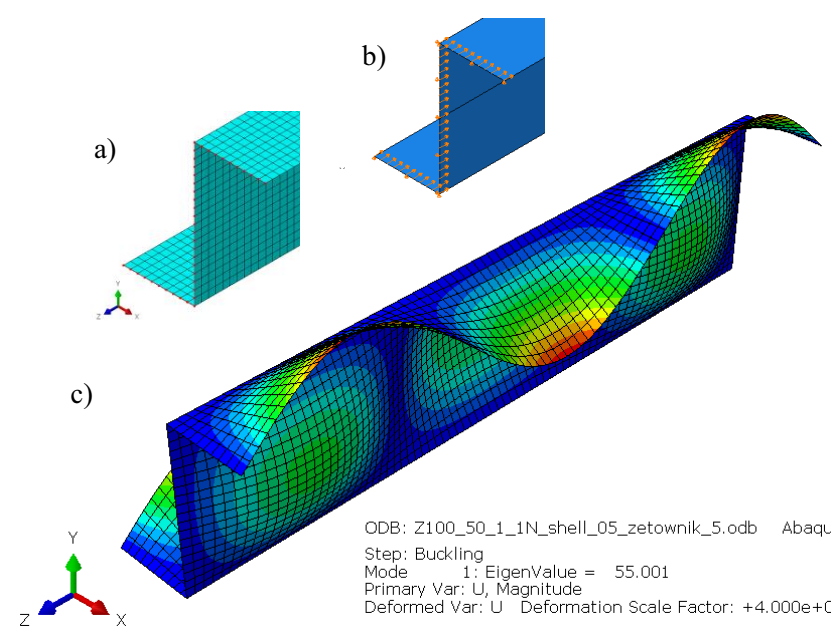

Fig. 8. Results of FEM calculations [6] for Example 1.: a) finite element mesh and boundary conditions, b) the way load is applied, c) buckling mode

Comparison of the ultimate resistance of the cross-section acc. the CPM and acc. Eurocode 3:

A) CPM (Chapter 3.7. step 11);

Relative slenderness: flange (CP): $\lambda_{p f}=(355 / 52.9)^{1 / 2}=2.59 ;$ web $(\mathrm{RP}) \underline{\lambda}_{p w}=(355 / 76)^{1 / 2}=2.16$, hence $\rho_{f}=0.36 ; b_{e f}=0.36 \cdot 50=18 \mathrm{~mm}$, and $\rho_{w}=0.42 ; \quad b_{\text {ew }}=0.42 \cdot 100=42 \mathrm{~mm}($ Fig. $7 \mathrm{c})$;

$A_{e f f}^{c p}=2(18 \cdot 1+21 \cdot 1)=78 \mathrm{~mm}^{2} ; \quad N_{e f f}^{c p}=A_{e f f}^{c p} f_{y} / \gamma_{M 0}=78 \cdot 355 / 1=\underline{27690 \mathrm{~N}}=\underline{27.7 \mathrm{kN}}$

B) Eurocode 3 [49,51]:

$\underline{\lambda}_{p f}=(355 / 32.7)^{1 / 2}=3.295 ; \rho_{f}=0.286 ; \quad b_{e f}=0.286 \cdot 50=14.3 \mathrm{~mm}$,

for the web without changes: $b_{\text {ew }}=42 \mathrm{~mm} ; A_{\text {eff }}=2(14.3 \cdot 1+21 \cdot 1)=70.6 \mathrm{~mm}^{2}$;

$N_{c, R d}=A_{\text {eff }} f_{y} / \gamma_{M 0}=70.6 \cdot 355 / 1=\underline{25063 \mathrm{~N}}=\underline{25.1 \mathrm{kN}}$

Resistance acc. the CPM is greater is than that from Eurocode 3 by approx.:

$[(27690-25063) / 25063] \cdot 100 \%=+\underline{10.5 \%}$.

\section{Example 2.}

Compute the local critical resistance and the design ultimate resistance of $\mathbf{C}$ cross-section (Fig.9a) in bending. The beam static scheme is shown in Fig.9b. Load P and support reactions are applied at the cross-section shear centre. The beam is protected against lateral-torsional buckling. The member is composed of two symmetrical segments, each $l_{s}=L / 2=1000 / 2=500 \mathrm{~mm}$ in length. 

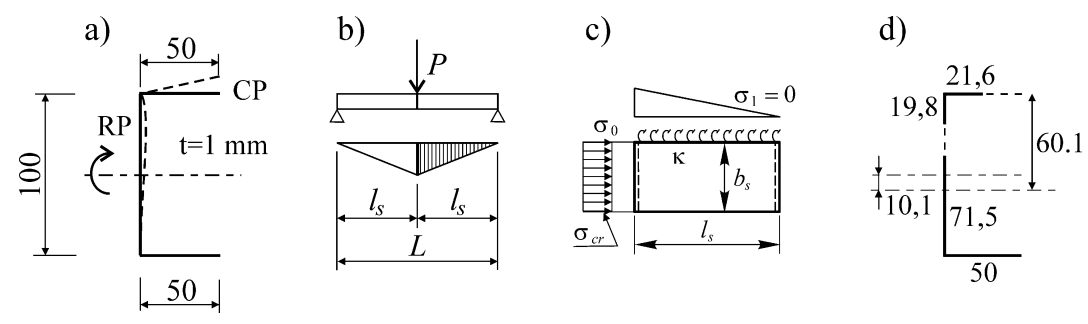

Fig. 9. a) Cross-section geometry, b) static scheme and the bending moment graph, c) stress state in CP, d) effective cross-section acc. the CPM

Data: S355 steel, $f_{y}=355 \mathrm{~N} / \mathrm{mm}^{2} ; E=210000 \mathrm{~N} / \mathrm{mm}^{2} ; v=0.3 ; L=1000 \mathrm{~mm} ; l_{s}=500 \mathrm{~mm}$; $J_{y}=333333 \mathrm{~mm}^{4} ; W_{y, e l}=6667 \mathrm{~mm}^{3} ; \gamma_{M 0}=1$.

Theoretical elastic bending resistance of the gross cross-section when local buckling is disregarded: $M_{e l}=W_{y, e l} f_{y} / \gamma_{M 0}=6667 \cdot 355 / 1=2366800 \mathrm{Nmm}=2.367 \mathrm{kNm}$.

Flange is Class $4(b / t=50>14 \varepsilon)$, web class will be specified after taking into account the shift of the neutral axis caused by flange buckling;

Euler stress and flexural rigidity (acc. Example 1):

flange: $\sigma_{E f}=76 \mathrm{~N} / \mathrm{mm}^{2} ; \quad D_{f}=19200 \mathrm{Nmm} ;$ web: $\sigma_{E w}=19 \mathrm{~N} / \mathrm{mm}^{2} ; D_{w}=19200 \mathrm{Nmm}$

Computations acc. the CPM procedure:

1) identification of CP: compressed flange $\sigma_{c r, f}^{o}=0.43 \cdot 76=32.7 \mathrm{~N} / \mathrm{mm}^{2}$; bent web $\sigma_{c r, w}^{o}=23.9 \cdot 19=$ $454.1 \mathrm{~N} / \mathrm{mm}^{2}$; C cross-section acc.Fig.9a is simple (Fig.1a), hence acc. condition (3.3): $\sigma_{c r, s}^{o}=$ $\min \{32.7 ; 454.1\}=32.7 \mathrm{~N} / \mathrm{mm}^{2}$ - the upper flange is CP, and web is RP;

2) due to a great difference in stress $\left(32.7<<454.1\left[\mathrm{~N} / \mathrm{mm}^{2}\right]\right)$, the initial assumption is $\kappa_{0}=0.5$;

3) estimation of the buckling length acc. (3.16): $l_{c r, 0}=50\left[(2.02-0.37 \cdot 0.5) / 0.5^{0.25}\right]=109 \mathrm{~mm}$;

4) RP is an internal plate loaded on one edge by the buckling upper flange (Fig.6b), hence coefficient acc. $(3.12)$ is $\eta_{2,0}=\left[33.4+50.7(100 / 109)^{2}\right]^{1 / 2}-2.78=5.94$;

5) buckling coefficient acc. study [33], for $\gamma_{s}=l_{s} / b_{s}=500 / 50=10$, and for linear stress distribution for $m_{l}=1-\sigma_{l} / \sigma_{0}=1$ is $k\left(\kappa_{0}=0.5\right)=1.005$, hence buckling stress for CP acc. (3.20): $\sigma_{c r, s, 0}=1.005 \cdot 76=76.38 \mathrm{~N} / \mathrm{mm}^{2}$;

6) critical stress of RP for $l_{c r, 0}$, i.e. for a single half-wavelength acc. (3.18): $\sigma_{c r, r 0}=210000 \cdot 1^{2} /\left(109^{2} \cdot 100^{4}\right) \cdot\left(11.32 \cdot 109^{4}+1.97 \cdot 100^{4}+12.06 \cdot 109^{2} \cdot 100^{2}\right)=570.5 \mathrm{~N} / \mathrm{mm}^{2} ;$

7) rotational spring stiffness (3.8): $C_{\theta, 0}=1 \cdot 5.94 \cdot 19200(1-76.38 / 570.5) / 100=988(\mathrm{Nmm} / \mathrm{rad}) / \mathrm{mm}$, hence the index of fixity $(3.6): \kappa=1 /[1+2 \cdot 19200 /(50 \cdot 988)]=0.563>\kappa_{0}=0.5$; 
8) first iteration step $(j=1): \kappa_{1}=0.563 ; l_{c r, 1}=105 \mathrm{~mm} ; \eta_{2,1}=6.13 ; k\left(\kappa_{1}\right)=1.048 ; \sigma_{c r, s, 1}=$ $1.048 \cdot 76=79.65 \mathrm{~N} / \mathrm{mm}^{2} ; \sigma_{c r, r 1}=553 \mathrm{~N} / \mathrm{mm}^{2} ; C_{\theta, 1}=1007(\mathrm{Nmm} / \mathrm{rad}) / \mathrm{mm} ; \kappa=0.567 \approx \kappa_{1}$

9) eventually, buckling coefficient acc. [33]: $k\left(\kappa_{1}=0.567\right)=1.051$; CP buckling stress was: $\sigma_{c r, s}=1.051 \cdot 76=79.9 \mathrm{~N} / \mathrm{mm}^{2}$; it is greater than the stress determined acc. [51] by: $[(79.9-32.7) / 32.7] \cdot 100 \%=\underline{144.3 \%}$.

10) local critical resistance of the cross-section in bending acc. (2.2): $M_{c r}{ }^{c p}=\sigma_{c r, s} W_{y, e l} / \gamma_{M 0}=$ $6667 \cdot 79.9 / 1=532700 \mathrm{Nmm}=\underline{0.533 \mathrm{kNm}}$, whereas the value estimated for the critical stress determined acc. [51]: $M_{c r}{ }^{E C 3}=\underline{0.218 \mathrm{kNm}}$.

Critical load: A) CPM: $P_{c r}{ }^{c p}=4 \cdot 0.533 / 1=\underline{2.13 \mathrm{kN}}$; B) Eurocode $3: P_{c r}{ }^{E C 3}=4 \cdot 0.218 / 1=\underline{0.87 \mathrm{kN}}$

FEM verification with the use of ABAQUS software [6] - Fig.10:

S4R shell elements were used having the dimensions $5 \times 5 \mathrm{~mm}$ (Fig.10a), "Buckling" procedure was selected, boundary conditions acc.Fig.10a: support by diaphragms, $1 \mathrm{~mm}$ in thickness, load applied acc. Fig.10b (central diaphragm $1 \mathrm{~mm}$ in thickness), concentrated force applied to the diaphragm at the cross-section shear centre. Critical stress acc. FEM: $P_{c r}{ }^{F E M}=2.2 \mathrm{kN}$

When compared with the CPM, the difference was approx $[(2.2-2.13) / 2.13] \cdot 100 \%=+3.3 \%$.

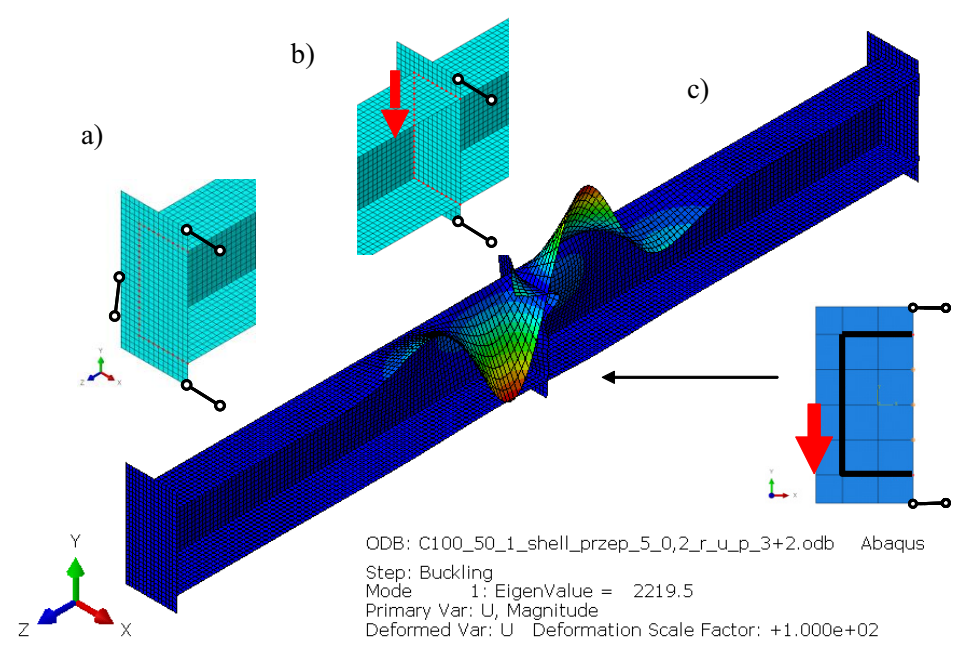

Fig. 10. Results of FEM calculations [6] for Example 2: a) finite element mesh and boundary conditions, b) the way load is applied, c) buckling mode 
Comparison of the ultimate resistance of the cross-section acc. the CPM and acc. Eurocode 3:

A) CPM (Chapter 3.7. step 11):

Relative slenderness of the flange (CP): $\lambda_{p f}=(355 / 79.9)^{1 / 2}=2.11 ; \rho_{f}=0.43 ; b_{e f}=0.43 \cdot 50=21.6 \mathrm{~mm}$; first shift of the neutral axis: $e_{1}=8.3 \mathrm{~mm}$; height of the web zone in compression: $h_{c}=58.3 \mathrm{~mm}$; stress ratio in the web: $\psi=\sigma_{2} / \sigma_{1}=-0.72$; the web is Class 4. $(h / t=100>42 \varepsilon /(0.67-0.33 \cdot 0.72)=78.7$; buckling coefficient acc. [51]: $k_{\sigma}=17.41$; critical stress for the web: $\sigma_{c r, w}=17.41 \cdot 19=331 \mathrm{~N} / \mathrm{mm}^{2}$; relative slenderness of the web (RP): $\underline{\lambda}_{p w}=(355 / 331)^{1 / 2}=1.036$; hence $\rho_{w}=0.85 ; b_{e w}=0.85 \cdot 58.3=$ $49.6 \mathrm{~mm} ; \quad b_{e 1}=0.4 \cdot 49.6=19.8 \mathrm{~mm} ; \quad b_{e 2}=0.6 \cdot 49.6=29.8 \mathrm{~mm}$; second shift of the neutral axis: $e_{2}=10.1 \mathrm{~mm}$; distance to the compressed flange $z_{c}=60.1 \mathrm{~mm}$; (Fig.9d), $J_{e f f}^{c p}=239855 \mathrm{~mm}^{4} ; W_{e f f}^{c p}=3991 \mathrm{~mm}^{3} ; M_{e f f}^{c p}=W_{e f f}^{c p} f_{y} / \gamma_{M 0}=3991 \cdot 355 / 1=1416800 \mathrm{Nmm}$

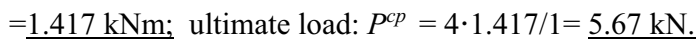

B) Eurocode 3 [49,51]: $\underline{\lambda}_{p f}=(355 / 32.7)^{1 / 2}=3.295 ; \rho_{f}=0.286 ; b_{e f}=0.286 \cdot 50=14.3 \mathrm{~mm}$; $e_{1}=10.9 \mathrm{~mm} ; h_{c}=60.9 \mathrm{~mm} ; \psi=\sigma_{2} / \sigma_{1}=-0.64 ; k_{\sigma}=15.8 ; \sigma_{c r, w}=15.8 \cdot 19=301 \mathrm{~N} / \mathrm{mm}^{2}$; $\underline{\lambda}_{p w}=(355 / 301)^{1 / 2}=1.09 ; \rho_{w}=0.81 ; \quad b_{e w}=0.81 \cdot 60.9=49.3 \mathrm{~mm} ; b_{e 1}=0.4 \cdot 49.3=19.7 \mathrm{~mm}$; $b_{e 2}=0.6 \cdot 49.3=29.6 \mathrm{~mm} ; e_{2}=13.5 \mathrm{~mm} ; z_{c}=63.5 \mathrm{~mm} ; J_{e f f}=208952 \mathrm{~mm}^{4} ; W_{\text {eff }}=3291 \mathrm{~mm}^{3}$; $M_{c, R d}=W_{\text {eff }} f_{y} / \gamma_{M 0}=3291 \cdot 355 / 1=1168300 \mathrm{Nmm}=\underline{1.168 \mathrm{kNm}} ; P^{E C 3}=4 \cdot 1.168 / 1=\underline{4.67 \mathrm{kN}}$. Ultimate load acc. the CPM is greater than that from Eurocode 3 by approx.: $[(5.67-4.67) / 4.67] \cdot 100 \%=+\underline{21.4 \%}$.

\section{Example 3.}

Compute the local critical resistance and the design ultimate resistance of the box cross-section (Fig.11a) in bending. The static scheme of the continuous beam is shown in Fig.11b. The member is provided with restraining diaphragms at the sites where concentrated forces are applied (at the centre of the span and on the supports). Because of the cross-section shape, the beam is not subjected to lateral-torsional buckling. Over the length of the span, the member is composed of two symmetrical segments $\mathrm{A}$ and $\mathrm{B}$, each $l_{s}=L / 2=4000 / 2=2000 \mathrm{~mm}$ in length. 

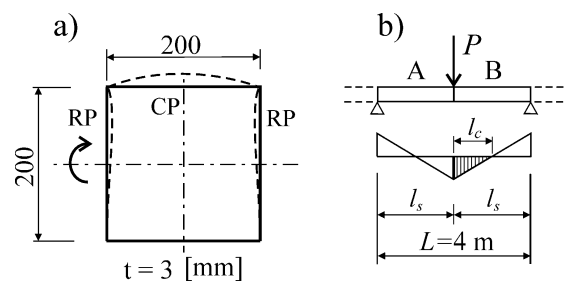

c)

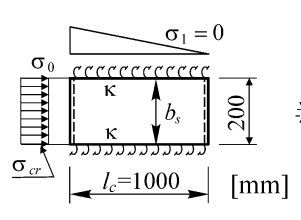

d)

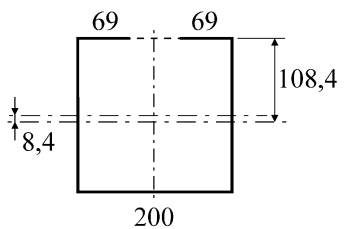

Fig. 11. a) Cross-section geometry, b) static scheme and the graph of the bending moment,

c) stress state in $\mathrm{CP}, \mathrm{d}$ ) effective cross-section acc. the CPM

Due to the distribution of the bending moment, over the segment length, a change in stress sign occurs, both for the upper and the lower flange. To determine the cross-section resistance, it is sufficient to take into account the stability of, e.g. the upper flange in segment "B". In study [33], it was shown that when a change in stress sign (from compression to tension) occurs, while determining critical stress, it is sufficient to consider only one compressed plate zone of the length of $l_{c}=1000 \mathrm{~mm}$. The problem is reduced to the examination of the stability of the plate of the upper flange acc. diagram shown in Fig. 11c.

Data: S355 steel, $f_{y}=355 \mathrm{~N} / \mathrm{mm}^{2} ; E=210000 \mathrm{~N} / \mathrm{mm}^{2} ; v=0.3 ; L=4000 \mathrm{~mm} ; l_{s}=2000 \mathrm{~mm}$; $l_{c}=1000 \mathrm{~mm} ; J_{y}=16 \cdot 10^{6} \mathrm{~mm}^{4} ; W_{y, e l}=16 \cdot 10^{4} \mathrm{~mm}^{3} ; \gamma_{M 0}=1$.

Theoretical elastic bending resistance of the gross cross-section when local buckling is disregarded: $M_{e l}=W_{y, e l} f_{y} / \gamma_{M 0}=16 \cdot 10^{4} \cdot 355 / 1=56.8 \cdot 10^{6} \mathrm{Nmm}=56.8 \mathrm{kNm}$.

Compressed flange is Class 4 . $(b / t=66.7>42 \varepsilon)$; the web class will be specified after taking into account the shift of the neutral axis caused by flange buckling;

Euler stress and flexural rigidity of component plates:

$\sigma_{E f}=\sigma_{E w}=42.75 \mathrm{~N} / \mathrm{mm}^{2} ; D_{f}=D_{w}=19200 \cdot 3^{3}=518400 \mathrm{Nmm}$;

Computations acc. the CPM procedure:

1) identification of CP: $\sigma_{c r, f}^{o}=4 \cdot 42.75=171 \mathrm{~N} / \mathrm{mm}^{2} ; \sigma_{c r, w}^{o}=23.9 \cdot 42.75=1022 \mathrm{~N} / \mathrm{mm}^{2}$; semicomplex cross-section (Fig.3c), hence acc. criterion (3.3): $\sigma_{c r, s}^{o}=\min \{171 ; 1022\}=171 \mathrm{~N} / \mathrm{mm}^{2}$

$-\mathrm{CP}$ is the compressed flange, and RPs are webs;

2) due to a great difference in stress $\left(171<1022\left[\mathrm{~N} / \mathrm{mm}^{2}\right]\right)$, an initial assumption is that $\kappa_{0}=0.4$;

3) from formula (3.14): $l_{c r, 0}=200\left[1-0.23 \cdot 0.4+0.07 \cdot 04^{2}-0.17 \cdot 0.4^{3}\right]=182 \mathrm{~mm}$;

4) RP is the internal plate loaded on one edge by the buckling upper flange (Fig.6b. and Fig.11a), hence coefficient acc. (3.12): $\eta_{2,0}=\left[33.4+50.7(200 / 182)^{2}\right]^{1 / 2}-2.78=6.95$;

5) acc. studies $[23,40]$, for $\gamma_{s}=l_{c} / b_{s}=1000 / 200=10$, and $m_{1}=1-\sigma_{1} / \sigma_{0}=1$ coefficient $k\left(\kappa_{0}=0.4\right)=5.18$, 
hence acc. (3.20): $\sigma_{c r, s, 0}=5.18 \cdot 42.75=221.4 \mathrm{~N} / \mathrm{mm}^{2}$;

6) from formula (3.18): $\sigma_{c r, r 0}=210000 \cdot 3^{2} /\left(182^{2} \cdot 200^{4}\right) \cdot\left(11.32 \cdot 182^{4}+1.97 \cdot 200^{4}+12.06 \cdot 182^{2} \cdot 200^{2}\right)=$ $1025 \mathrm{~N} / \mathrm{mm}^{2}$;

7) from formula (3.8): $C_{\theta, 0}=1 \cdot 6.95 \cdot 518400(1-221.4 / 1025) / 200=14123(\mathrm{Nmm} / \mathrm{rad}) / \mathrm{mm}$, hence from formula (3.6): $\kappa=1 /[1+2 \cdot 518400 /(200 \cdot 14123)]=0.73>\kappa_{0}=0.4 ;$

8) first iteration step $(j=1): \kappa_{1}=0.73 ; l_{c r, 1}=161 \mathrm{~mm} ; \eta_{2,1}=7.786 ; k\left(\kappa_{1}\right)=5.99 ; \sigma_{c r, s, 1}=256.1 \mathrm{~N} / \mathrm{mm}^{2}$; $\sigma_{c r, r 1}=1060 \mathrm{~N} / \mathrm{mm}^{2} ; C_{\theta, 1}=15305(\mathrm{Nmm} / \mathrm{rad}) / \mathrm{mm} ; \kappa=0.747>\kappa_{1} ;$ second iteration step $(j=2): \kappa_{2} \approx 0.75 ; l_{c r, 2}=159 \mathrm{~mm} ; \eta_{2,2}=7.88 ; k\left(\kappa_{2}\right)=6.07$; $\sigma_{c r, s, 2}=259.5 \mathrm{~N} / \mathrm{mm}^{2} ; \sigma_{c r, r 2}=1055 \mathrm{~N} / \mathrm{mm}^{2} ; C_{\theta, 2}=15401(\mathrm{Nmm} / \mathrm{rad}) / \mathrm{mm} ; \kappa=0.75=\kappa_{2} ;$

9) eventually $k\left(\kappa_{2}\right)=6.07$; buckling stress: $\sigma_{c r, s}=259.5 \mathrm{~N} / \mathrm{mm}^{2}$; it is greater than the stress determined acc.[51] by: $[(259.5-171) / 171] \cdot 100 \%=\underline{51.8 \%}$.

10) local critical resistance of the cross-section in bending acc. (2.2): $M_{c r}{ }^{c p}=W_{y, e l} \sigma_{c r, s} / \gamma_{M 0}=$ $16 \cdot 10^{4} \cdot 259.5 / 1=41.52 \cdot 10^{6} \mathrm{Nmm}=\underline{41.5 \mathrm{kNm}}$, whereas the value estimated for critical stress determined acc. [51]: $M_{c r}{ }^{E C 3}=27.4 \mathrm{kNm}$.

The critical load: A) CPM: $P_{c r}{ }^{c p}=8 \cdot 41.5 / 4=\underline{83 \mathrm{kN}}$; B) Eurocode $3 P_{c r}{ }^{E C 3}=8 \cdot 27.4 / 4=\underline{54.8 \mathrm{kN}}$ FEM verification with the use of ABAQUS software [6] - Fig.12:

S4R shell elements were used having the dimensions 10x10 mm (Fig.12a), "Buckling" procedure was selected, boundary conditions acc. Fig.12a: continuous support along the cross-section midline in three directions, load applied acc. Fig.12b (the thickness of the invisible membrane at the member midspan was $1 \mathrm{~mm}$ ). The critical load acc. FEM: $P_{c r}{ }^{F E M}=85.22 \mathrm{kN}$. When compared with the CPM, the difference was approx. $[(85.22-83) / 83] \cdot 100 \%=+2.7 \%$.

Comparison of the ultimate resistance of the cross-section acc. the CPM and acc. Eurocode 3:

A) CPM (Chapter 3.7. step 11):

Flange relative slenderness (CP): $\lambda_{p f}=(355 / 259.5)^{1 / 2}=1.17 ; \rho_{f}=0.69 ; b_{e f}=0.69 \cdot 200=138 \mathrm{~mm}$; the neutral axis shift: $e_{1}=8.4 \mathrm{~mm}$; height of the web zone in compression: $h_{c}=108.4 \mathrm{~mm}$; stress ratio in the web: $\psi=\sigma_{2} / \sigma_{1}=-0.85$; the web is Class 3. $(h / t=66.7<42 \varepsilon /(0.67-0.33 \cdot 0.85)=87.3$; $J_{e f f}^{c p}=13983740 \mathrm{~mm}^{4} ; W_{e f f}^{c p}=129001 \mathrm{~mm}^{3}$; $M_{e f f}^{c p}=W_{e f f}^{c p} f_{y} / \gamma_{M 0}=129001 \cdot 355 / 1=45795000 \mathrm{Nmm}=\underline{45.8 \mathrm{kNm}} ;$

Ultimate load: $P^{c p}=8 \cdot 45.8 / 4=\underline{91.6 \mathrm{kN}}$ 

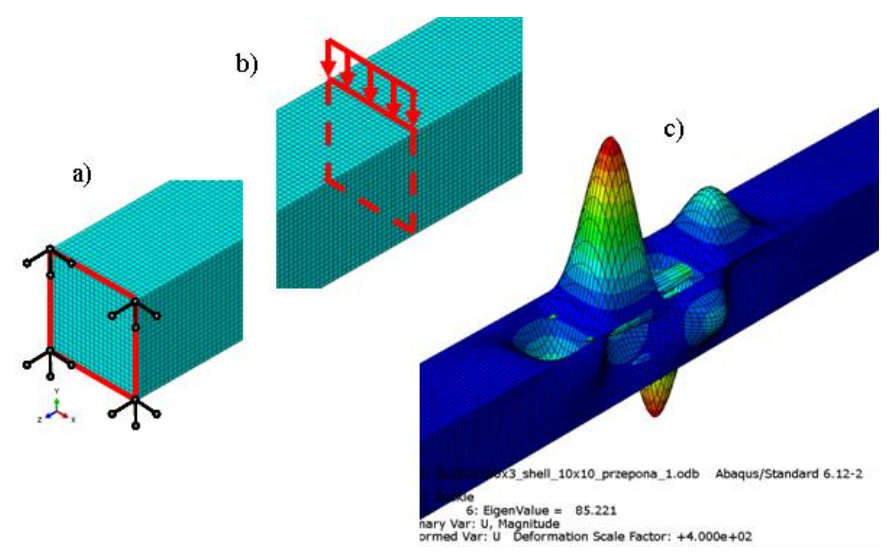

Fig. 12. Results of FEM calculations [6] for Example 3.: a) finite element mesh and boundary conditions, b) the way load is applied, c) buckling mode

B) Eurocode $3[49,51]$ :

$\underline{\lambda}_{p f}=(355 / 171)^{1 / 2}=1.44 ; \quad \rho_{f}=0.59 ; \quad b_{e f}=0.59 \cdot 200=118 \mathrm{~mm}$;

$e_{1}=11.4 \mathrm{~mm} ; h_{c}=111.4 \mathrm{~mm} ; \psi=\sigma_{2} / \sigma_{1}=-0.8$;

the web is Class 3. $(h / t=66.7<42 \varepsilon /(0.67-0.33 \cdot 0.8)=84)$;

$J_{\text {eff }}=13259054 \mathrm{~mm}^{4} ; W_{\text {eff }}=119022 \mathrm{~mm}^{3}$;

$M_{c, R d}=W_{\text {eff }} f_{y} / \gamma_{M 0}=119022 \cdot 355 / 1=42253000 \mathrm{Nmm}=42.2 \mathrm{kNm} ; P^{E C 3}=8 \cdot 42.2 / 4=\underline{84.4 \mathrm{kN}}$.

Ultimate load acc. the CPM is greater than that from Eurocode 3 by approx.:

$[(91.6-84.4) / 84.4] \cdot 100 \%=+\underline{8.5 \%}$.

\section{COMPARISON OF THE CPM AND EXPERIMENTAL RESULTS}

Table 1 shows the comparison of ultimate cross-section resistance determined experimentally in studies $[2,11,21,25,26]$ with theoretical calculations, according to Eurocode $3[49,50,51]$ and the results obtained with the CPM presented in this study. In order to calculate resistance in accordance with individual research models, steel yield limit values $\left(f_{y}^{e x}\right)$, determined experimentally during tests, were assumed. Table 1 lists the following information: Column 1 - reference number, Column 2 - type of cross-section and method of load application, Column 3 - research model type and basic cross-section dimensions, Column 4 - slenderness CP $\left(\lambda_{c p}\right)$, Column $5-f_{y}^{e x}\left[\mathrm{~N} / \mathrm{mm}^{2}\right]$, Column $6-$ $M_{u l t} e^{e x}$, ultimate resistance determined experimentally, Column $7-M_{e l}$, theoretical elastic bending 
resistance for the gross cross-section, acc. the formula: $M_{e l}=W_{e l} f_{y}^{e x}$, Column $8-M_{e f f}^{E C 3}$, the crosssection resistance, determined acc. Eurocode 3 [49,50,51], Column $9-M_{c r}{ }^{c p}$, local critical resistance within the elastic range, acc. the CPM, Column $10-M_{\text {eff }}^{c p}$, ultimate cross-section resistance, acc. the CPM. It should be noted that all resistances, measured by means of the bending moment, are given in $[\mathrm{Nm}]$.

On the basis of comparison of the values presented in Table 1, the following conclusions can be drawn: 1$)$ in a majority of cases, a very good (0.9-1) or good (0.8-0.9) relationship (Column 12) is found between the ultimate resistance, determined acc. the CPM $\left(M_{\text {eff }}^{c p}\right)$, and the ultimate resistance determined experimentally $\left.\left(M_{u l t}{ }^{e x}\right), 2\right)$ in the majority of cases, the relationship between resistance calculated according to Eurocode $3\left(M_{e f f}^{E C 3}\right)$, and $M_{u l t}{ }^{e x}$ (Column 11) is too conservative, 3$) M_{e f f}^{c p}$ is greater than $M_{\text {eff }}^{E C}$ (Column 13), ranging from approx. 4\% (case 11) to approx. 48\% (case 9), 4) in each case, theoretical elastic bending resistance for the gross cross-section $\left(M_{e l}\right)$ is larger than $M_{e f f}{ }^{c p}$ from approx. $1 \%$ (case 13 ) to approx. $150 \%$ for case 9,5 ) the most significant differences between $M_{u l t}^{e x}$, and $M_{e f f}^{c p}$ are found for cases 7,9 , and 12, in which the CP is an eccentrically compressed

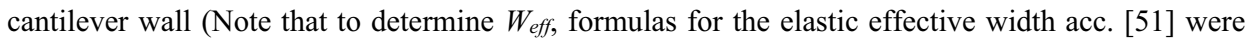
used), 6) the smallest differences were identified in those cases $(1,2,3,5)$, in which the $\mathrm{CP}$ is an axially compressed cantilever wall, or an axially compressed internal wall (cases 10 and 11), 7) in many cases, the local critical cross-section resistance $\left(M_{c r}{ }^{c p}\right)$ is lower than $M_{e l}$, thus limiting the Vlasov theory application to the range: $M \leq M_{c r}{ }^{c p}$.

\section{Conclusions}

Local buckling of the most loaded bar segment can be decisive for the ultimate design resistance of the thin-walled cross-section. However, the cross-section local buckling is, as a rule, most affected by the weakest plate (wall), which is referred to as the critical plate in this study. CP is elastically restrained in RP (or RPs) and variable stress distribution may occur over its length. Only in the socalled "zero" cross-section, the elastic restraint of the component walls does not occur. If that is the case, calculations can be performed as before, i.e. on the basis of the concept of separation of simply supported plate elements. However, in many technically significant cases, the effect of the elastic restraint of component plates (walls), like for distortional buckling, can be considered in the computational model. Taking into account the influence of the elastic restraint of plate elements and the longitudinal stress variation results in a more accurate computational model. 


\begin{tabular}{|c|c|c|c|c|c|c|c|c|c|c|c|c|c|c|}
\hline z: & $\approx$ & ণ্ণ & $\stackrel{n}{\check{ユ}}$ & $\stackrel{\Omega}{\Xi}$ & 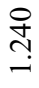 & $\stackrel{n}{=}$ & 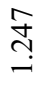 & 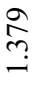 & $\underset{\stackrel{\sim}{\sim}}{\stackrel{\sim}{\sim}}$ & $\begin{array}{l}\stackrel{\infty}{\infty} \\
\stackrel{+}{\sim}\end{array}$ & 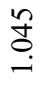 & $\underset{\Xi}{\vec{J}}$ & $\begin{array}{l}\stackrel{0}{\beth} \\
=\end{array}$ & $\begin{array}{l}\infty \\
\stackrel{0}{1} \\
\text { ్ }\end{array}$ \\
\hline so & $\simeq$ & $\begin{array}{l}\stackrel{\leftrightarrow}{\circ} \\
\stackrel{0}{0}\end{array}$ & $\stackrel{\ominus}{\longrightarrow}$ & $\stackrel{\circ}{\grave{0}}$ & 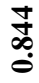 & $\begin{array}{l}\hat{b} \\
\stackrel{0}{0}\end{array}$ & $\begin{array}{l}\stackrel{\circ}{\circ} \\
\text { ळ. }\end{array}$ & 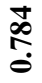 & ๙ু & $\stackrel{\bar{\sigma}}{\dot{\theta}}$ & $\begin{array}{l}\text { ڤ̆ } \\
\text { ڤ̊ }\end{array}$ & $\begin{array}{l}\hat{\infty} \\
\stackrel{0}{0} \\
0\end{array}$ & $\frac{\mathfrak{d}}{\stackrel{\sigma}{0}}$ & $\begin{array}{c}\mathscr{\infty} \\
\stackrel{0}{0}\end{array}$ \\
\hline & & $\approx$ & $\approx$ & $n$ & - & + & $a$ & a) & N & $m$ & $\sqrt{5}$ & 5 & $F$ & \\
\hline
\end{tabular}

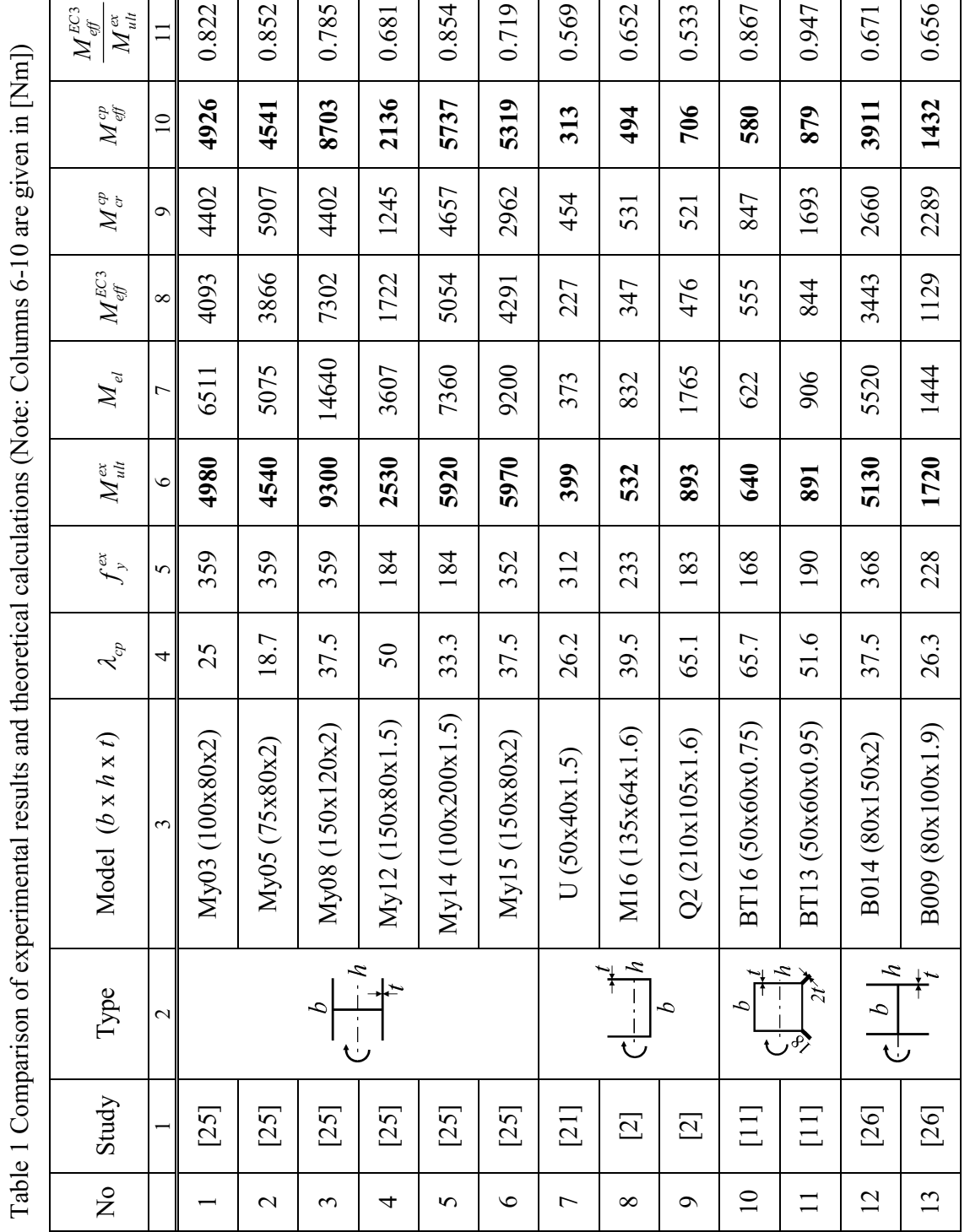


The study presents the method of determination of the local critical resistance and the ultimate resistance of the thin-walled cross-section. The method relies on the analysis of the behaviour of the $\mathrm{CP}$ and that of RP (or RPs) rigidly connected to CP. The division of cross-sections into: 1) simple, 2) semi-complex and, 3) complex ones, presented in the study, makes it possible to identify the CP for the first two types. That is done on the basis of simplified condition (3.3) applied to a certain cross-section load state. The method of unambiguous CP identification in complex cross-sections will be presented in a separate study. The index of fixity of the CP edge can be estimated on the basis of the assumed form of forced RP deformation, while taking into account the effect of compressive stress in its plane. Plate buckling coefficients $(k)$ for CPs, elastically restrained in the manner described above and subjected to longitudinal stress variation, can be determined on the basis of the author's studies $[31,32,33,34,35,36,37,38,39,40,41,42]$. The local critical resistance of the thin-walled cross-section, estimated on the basis of the $\mathrm{CP}$ buckling, sets a limit on the validity of the Vlasov theory on thin-walled bars with rigid cross-section contour.

In order to determine the design ultimate resistance of thin-walled cross-section, the effective width method can be applied, used for individual plates, acc. assumptions presented in Chapter 3.7, step 11. The relative slenderness is determined on the basis of appropriate critical stress. For CP, this stress takes into consideration the index of fixity and longitudinal stress variation. For RP, on the same edge, simple support and constant stress distribution along the whole length can be assumed. Such assumptions make it possible to determine the design ultimate resistance of the cross-section in a way that is sufficiently accurate from the technical standpoint.

When using the CPM in practice, it is necessary to make sure that in the thin-walled cross-section of concern, the conditions of continuity of displacements (angles of rotation) and forces (bending moments) at edges of CP connection to RP (or RPs) are met. In technical calculations, it can be assumed that this continuity occurs in cold-bent and hot-rolled cross-sections, and also in full penetration butt-welded or double welded fillet types. However, the issue of the elastic restraint of the component wall joined with a single fillet weld (e.g., in box cross-sections) requires further research. Currently, it can be approximately assumed that the reduced index of fixity $\left(\kappa^{*}\right)$ can be estimated acc. formula: $\kappa^{*}=a \kappa / t_{s}$ (where: $a$-thickness of a single fillet weld, $\kappa$-index determined for complete continuity of displacements and forces $t_{s}-\mathrm{CP}$ thickness). The method presented in the study makes it possible to determine, either by hand or using spreadsheets, the local critical resistance and the design ultimate resistance of thin-walled cross-sections with relatively low effort. That allows, for example, preliminary design and simple verification of FEM calculations. 


\section{REFERENCES}

1 Bulson P.S. The Stability of Flat Plates. Chatto and Windus. London 1970.

2 Beale R.G., Godley M.H.R, Enjily V. A theoretical and experimental investigation into cold-formed channel sections in bending with the unstiffened flanges in compression. Computer \& Structures 79, 2001, 2403-2411.

3 Chudzikiewicz A. General theory of thin-walled bars stability taking into account the cross-section deformability. Part I: Simple cross-section bars (in Polish). Rozprawy Inżynierskie, Vol. VIII, 1960, Series 3 , 423-459.

4 Chudzikiewicz A. General theory of thin-walled bars stability taking into account the cross-section deformability. Part II: Complex cross-sections bars (in Polish). Rozprawy Inżynierskie, Vol. VIII, 1960, Series 4, 805-841.

5 Hancock G.J. Cold-formed steel structures. Journal of Constructional Steel Research 2003, 58, 473-487.

6 Hibbit, Karlsson \& Sorensen Inc. ABAQUS/standard user's manual. Hibbit, Karlsson \& Sorensen, Inc, 1995.

7 Ignatowicz R.L. The theoretical and experimental analysis of resistance of the cold-formed steel columns with box section (in Polish). PhD thesis. Instytut Budownictwa Politechniki Wrocławskiej, Series PRE 52/99, Wrocław 1999.

8 Jakubowski S. Buckling of thin-walled girders under compound load. Thin-Walled Structures 1988, 6,129-150.

9 Jakubowski S. The matrix analysis of stability and free vibrations of walls of thin-walled girders (in Polish). Archiwum Budowy Maszyn 1986, Vol. XXXIII, Series 4, 357-376.

10 Kalyanaraman V. Local buckling of cold-formed steel members. Journal of the Structural Division 1979, Vol. 105, No.ST5, 813-828.

11 Kotełko M., Lim T.H., Rhodes J. Post - failure behaviour of box section beams under pure bending (an experimental study). Thin-Walled Structures 38, (2000), 179-194.

12 Kotełko M. Thin-walled structures resistance and failure mechanisms (in Polish). Wydawnictwa Naukowo Techniczne, Warszawa 2011.

13 Kowal Z. The stability of compressed flange of plate girder with a box section (in Polish). Zeszyty Naukowe Politechniki Wrocławskiej, Budownictwo 1965, 122, 73-85.

14 Kowal Z. The stability top metal plate of pontoon foundation (in Polish). Węgiel Brunatny 1966; 4: $331-333$.

15 Kowal Z., Szychowski A. Experimental determination of critical loads in thin-walled bars with Z-section subjected to warping torsion. Thin-Walled Structures 75, 2014, 87-102.

16 Królak M, editor. Post-critical states and limit load-carrying capacity of thin-walled girders with flat walls (in Polish). Warsaw, Lodz: State Scientific Publishers; 1990.

17 Kubica E. Ultimate resistance and longitudinal stiffness of thin-walled steel members (in Polish). Oficyna Wydawnicza Politechniki Wrocławskiej. Wrocław 2005.

18 Li L-y., Chen J-k. An analytical model for analyzing distortional buckling of cold-formed steel sections. ThinWalled Structures 46, 2008, 1430-1436.

19 Nassar G. Das Ausbeulen dünnwandiger Querschnitte unter einachsig aussermittiger Druckbeanspruchung, Der Stahlbau, H.10, 1965, 311-316.

20 Papangelis J.P., Hancock G.J. Computer analysis of thin-walled structural members, Computer \& Structures Vol. 56. No. 1. 1995, 157-176.

21 Pastor M.M., Roure F. Open cross - section beams under pure bending. I. Experimental investigations. ThinWalled Structures 46 (2008) 476-483.

22 Potrzeszcz-Sut B., Szychowski A. Neural approximation of the buckling coefficient of compression flange of box girder evenly loaded transversely. Applied Mechanics and Materials (797), 2015, 137-144.

23 Potrzeszcz-Sut B., Szychowski A. Neural prediction of internal walls buckling coefficient of thin-walled member. Konstrukcje betonowe i metalowe. Wydawnictwa Uczelniane Uniwersytetu Technologiczno Przyrodniczego w Bydgoszczy, Bydgoszcz 2015, 259 - 266.

24 Protte W. Zur Beulung versteifter Kastenträger mit symmetrischem Trapez-Querschnitt unter BiegemomentenNormalkraft- und Querkraftbeanspruchung. Techn.Mitt.Krupp.-Forsch.Ber. Band 1976; 34, H.2. 
25 Rusch A., Lindner J. Remarks to the Direct Strength Method. Thin-Walled Structures 39 (2001) 807-820.

26 Rusch A., Lindner J. Load carrying capacity of thin-walled I-sections subjected to bending about the z-axis (in German). Stahlbau 1999; 68: 457-67.

27 Rykaluk K. Residual welding stresses in chosen ultimate bearing capacity (in Polish). Prace Naukowe Instytutu Budownictwa Politechniki Wrocławskiej, No 29, Series: Monografie 11, Wrocław 1981.

28 Schafer B.W., Ádány, S. Buckling analysis of cold-formed steel members using CUFSM: conventional and constrained finite strip methods. Proceedings of the Eighteenth International Specialty Conference on ColdFormed Steel Structures, Orlando, FL. October 2006.

29 Schafer B.W., Peköz T. Direct strength prediction of cold-formed steel members using numerical elastic buckling solutions. In: Shanmugan NE et al, Thin-walled-structures. The Netherlands: Elsevier, 1998, 137-44.

30 Schafer B.W. Review: The direct strength method of cold-formed steel member design. Stability and Ductility of Steel Structures, D. Camotim et al. (Eds.) Lisbon, Portugal, September 6-8, 2006.

31 Szychowski A. A theoretical analysis of the local buckling in thin-walled bars with open cross-section subjected to warping torsion. Thin-Walled Structures 76 (2014) 42-55.

32 Szychowski A. The stability of eccentrically compressed thin plates with a longitudinal free edge and with stress variation in the longitudinal direction. Thin-Walled Structures 2008, 46(5), 494-05.

33 Szychowski A., Stability of cantilever walls of steel thin-walled bars with open cross-section. Thin-Walled Structures 94 (2015), 348-358.

34 Szychowski A. Stability of eccentrically compressed cantilever wall of a thin-walled member (in Polish). Journal of Civil Engineering, Environment and Architecture (JCEEA) Vol. XXXII, Series. 62 (3/II/15), 2015, 439-457.

35 Szychowski A. Local stability of the compressed flange of a cold-formed thin-walled section (in Polish). Zeszyty Naukowe Politechniki Rzeszowskiej Nr 276, Series: Budownictwo i Inżynieria Środowiska, Z. 58, No. 3/2011/II, 307-314.

36 Szychowski A. Stability of unsymmetrical elastically restrained internal plates with longitudinal stress variation (in Polish). Zeszyty Naukowe Politechniki Rzeszowskiej $\mathrm{Nr}$ 283, Series: Budownictwo i Inżynieria Srodowiska, Z. 59, No. 3/2012/II, 429-436.

37 Szychowski A. Local buckling of cantilever wall of thin-walled member with longitudinal and transverse stress variation (in Polish). Budownictwo i Architektura 14 (2) 2015, pp.113-121.

38 Szychowski A. The stability of elastically restrained cantilever plates with stress variation in the longitudinal direction (in Polish). Materiały 56 Konferencji Naukowej KILiW PAN i KN PZITB, Kielce-Krynica 2010, 867-874.

39 Szychowski A. The stability of compressed flange of box gilder with longitudinal stress variation (in Polish). Proceedings of the $12^{\text {th }}$ International Conference on Metal Structures, Wroclaw, Poland 15-17 June 2011, 202-211.

40 Szychowski A. Buckling of internal walls in thin-walled members. Short papers. Scientific-Technical Conference of Metal Structures - ZK 2014, Kielce - Suchedniów, July 2014, 81-84.

41 Szychowski A. Coefficients of local buckling of the compressed flange of a cold-formed member. Proceedings of the $2^{\text {nd }}$ Polish-Ukrainian International Conference on Current Problems in Metal Structures, Gdansk, 27-28 November 2014.

42 Szychowski A. Buckling of the stiffened flange of the thin-walled member at longitudinal stress variation. Archives of Civil Engineering, Vol. LXI, Issue 3/2015, pp.149 - 168.

43 Timoshenko S.P., Gere J.M. Theory of Elastic Stability. Part II. McGraw-Hill, New York, N.Y. 1961.

44 Vlasov V.Z. Thin-Walled Elastic Beams. Israel Program for Scientific Translations, Jerusalem, 1961.

$45 \mathrm{Yu} \mathrm{C}$, Schafer B.W. Effect of longitudinal stress gradient on the ultimate strength of thin plates. Thin-Walled Structures 2006, 44, 787-799.

$46 \mathrm{Yu} \mathrm{C}$, Schafer B.W. Effect of longitudinal stress gradients on elastic buckling of thin plates. J Eng Mech ASCE 2007, 133(4), 452-63.

47 Zienkiewicz O.C., Taylor R.L., Zhu J.Z., The Finite Element Method: Its Basis and Fundamentals, Seventh Edition. Elsevier, United Kingdom 2013.

48 Handbook of Structural Stability. Edited by Column Research Committee of Japan, Corona Publishing Company, Tokyo 1971. 
49 EN 1993-1-1:2006 Eurocode 3 - Design of steel structures - Part 1-1: General rules and rules for buildings.

50 EN 1993-1-3:2006 Eurocode 3 - Design of steel structures - Part 1-3: General rules - Supplementary rules for cold-formed members and sheeting.

51 EN 1993-1-5:2006 Eurocode 3 - Design of steel structures - Part 1-5: Plated structural elements

52 NAS. North American specification for the design of cold-formed steel structural members. 2007 edition. Washington, DC, USA: American Iron and Steel Institute; 2007.

Received 04. 04. 2016

Revised 18. 05. 2016

\section{LIST OF FIGURES AND TABLES:}

Fig. 1. Examples of simple (a) and complex (b) cross-sections acc. definition [3, 4]

Rys. 1. Przykłady przekrojów prostych (a) i złożonych (b) wg definicji [3, 4]

Fig. 2. Types of "critical plates"

Rys. 2. Typy ,płyt krytycznych"

Fig. 3. Examples of semi-complex cross-sections and their computational modelling

Rys. 3. Przykłady przekrojów pół-złożonych i sposób ich modelowania

Fig. 4. Cross-section division into critical (CP) and restraining (RP) plates

Rys. 4. Podział przekroju na płyty krytyczne (CP) i płyty usztywniające (RP)

Fig. 5. Examples of "zero" cross-sections and selected values of coefficient $\delta$

Rys. 5. Przykłady przekrojów „zerowych” oraz wybrane wartości współczynnika $\delta$

Fig. 6. Types of restraining plates with width of $b_{r}$ and thickness of $t_{r}$ acc. [10]

Rys. 6. Podział płyt usztywniających o szerokości $b_{r}$ i grubości $t_{r}$ wg [10]

Fig. 7. a) Cross-section geometry, b) division into CPs and RP, c) effective cross-section acc. the CPM,

d) mode of local buckling for a single half-wavelength

Rys. 7. a) geometria przekroju, b) podział na CPs i RP, c) przekrój efektywny wg CPM, d) postać lokalnego wyboczenia dla pojedynczej półfali

Fig. 8. Results of FEM calculations [6] for Example 1: a) finite element mesh and boundary conditions,

b) the way load is applied, c) buckling mode

Rys. 8. Wyniki obliczeń MES [6] dla przykładu 1.: a) siatka elementów skończonych i warunki brzegowe,

b) sposób przyłożenia obciążenia c) postać wyboczenia

Fig. 9. a) Cross-section geometry, b) static scheme and the bending moment graph, c) stress state in CP,

d) effective cross-section acc. the CPM

Rys. 9. a) geometria przekroju, b) schemat statyczny i wykres momentu zginającego, c) stan naprężenia w CP, d) przekrój efektywny wg CPM 
Fig. 10. Results of FEM calculations [6] for Example 2.: a) finite element mesh and boundary conditions,

b) the way load is applied, c) buckling mode

Rys. 10. Wyniki obliczeń MES [6] dla przykładu 2.: a) siatka elementów skończonych i warunki brzegowe,

b) sposób przyłożenia obciążenia, c) postać wyboczenia

Fig. 11. a) Cross-section geometry, b) static scheme and the graph of the bending moment,

c) stress state in $\mathrm{CP}$, d) effective cross-section acc. the CPM

Rys. 11. a) geometria przekroju, b) schemat statyczny i wykres momentu zginającego, c) stan naprężenia w CP, d) przekrój efektywny wg CPM

Fig. 12. Results of FEM calculations [6] for Example 3.: a) finite element mesh and boundary conditions,

b) the way load is applied, c) buckling mode

Rys. 12. Wyniki obliczeń MES [6] dla przykładu 3.: a) siatka elementów skończonych i warunki brzegowe,

b) sposób przyłożenia obciążenia, c) postać wyboczenia

Tab. 1. Comparison of experimental results and theoretical calculations (Note: Columns 6-10 are given in $[\mathrm{Nm}])$

Tab. 1. Porównanie wyników badań eksperymentalnych i obliczeń teoretycznych (uwaga: kol.6 - 10 podano $\mathrm{w}[\mathrm{Nm}])$ 


\section{OBLICZANIE NOŚNOŚCI PRZEKROJU CIENKOŚCIENNEGO NA WYBOCZENIE LOKALNE METODĄ „PLYTY KRYTYCZNEJ”}

Slowa kluczowe: elementy cienkościenne, sprężyste zamocowanie, „płyta krytyczna”, wyboczenie lokalne, wzdłużna zmienność naprężeń, lokalna nośność krytyczna, obliczeniowa nośność graniczna przekroju

\section{STRESZCZENIE:}

Stosowane obecnie w budownictwie metalowym pręty cienkościenne należą do grupy elementów, których nośność przekroju jest warunkowana zjawiskami lokalnej lub dystorsyjnej utraty stateczności. Przekrój poprzeczny klasy 4. jest na ogół złożony ze smukło - płytowych ścianek, które w analizie można modelować wprost jako płyty. W aktualnie obowiązującej normie europejskiej EC3, zjawiska wyboczenia lokalnego i wyboczenia dystorsyjnego, pomimo różnic w długościach wyboczeniowych, uwzględnia się poprzez redukcję nośności przekroju. Stosuje się tutaj metodę szerokości efektywnej (dla wyboczenia lokalnego) oraz grubości zredukowanej (dla wyboczenia dystorsyjnego). Po uwzględnieniu obu zjawisk, otrzymujemy przekrój efektywny służący do obliczania odpowiednich charakterystyk geometrycznych (np. $A_{e f f}, W_{e f f}$ ). Natomiast ogólną utratę stateczności pręta uwzględnia się za pomocą współczynnika redukcyjnego obliczanego na podstawie smukłości względnej ogólnej utraty stateczności. W związku z tym, poprawne wyznaczenie naprężeń krytycznych wyboczenia lokalnego (w zakresie sprężystym) nabiera szczególnego znaczenia. Stanowi bowiem podstawę do wyznaczenia: 1) szerokości efektywnych poszczególnych płyt (ścianek), 2) naprężeń krytycznych wyboczenia dystorsyjnego (zastępczy przekrój poprzeczny usztywnienia składa się z odpowiednich szerokości efektywnych), oraz 3) ogólnej smukłości względnej elementu.

W normach EC3 dotyczących projektowania elementów cienkościennych (o przekroju klasy 4.) przyjęto koncepcję separacji płyt składowych przekroju przy założeniu ich swobodnego podparcia na podłużnych krawędziach łączenia. Ponadto pominięto, często występujący w praktyce, efekt wzdłużnej zmienności naprężeń. Takie założenia upraszczające odbiegają od rzeczywistego zachowania się elementu cienkościennego pod obciążeniem. Liczne badania doświadczalne oraz symulacje numeryczne (np. MES) wykazują, że w rzeczywistych przekrojach cienkościennych występuje wzajemne sprężyste zamocowanie ścianek składowych. Ponadto, w wielu technicznie ważnych przypadkach, występuje wzdłużna zmienność naprężeń.

W pracy przedstawiono metodę obliczeń nośności przekroju cienkościennego wrażliwego na wyboczenie lokalne na podstawie utraty stateczności najsłabszej płyty (ścianki). Punktem wyjścia jest założenie, że w przekroju cienkościennym można wyróżnić ściankę „najsłabszą”, która jest sprężyście zamocowana w sąsiedniej ściance usztywniającej (RP). „Płytą krytyczną” (CP) nazwano tę ściankę kształtownika cienkościennego, która w danym stanie naprężenia charakteryzuje się najniższymi naprężeniami krytycznymi. Założono, że połączenie płyty krytycznej z płytą podpierającą jest sztywne, tzn. na podłużnej krawędzi ich łączenia zachowane są warunki ciągłości przemieszczeń (kątów obrotu) i sił (momentów zginających). Dalej ściankę krytyczną modelowano, w zależności od warunków brzegowych, jako sprężyście zamocowaną przeciw obrotowi płytę przęsłową lub wspornikową. Oznacza to, że naprężenia krytyczne dla płyty krytycznej są wyższe niż przy normowym założeniu jej swobodnego podparcia. Stopień sprężystego zamocowania opisano za pomocą wskaźnika utwierdzenia $\kappa$, zmieniającego się od 0 dla swobodnego 
podparcia, do 1 dla pełnego utwierdzenia. Wskaźnik ten oszacowano w oparciu o założoną postać wymuszonego odkształcenia płyty usztywniającej, przy uwzględnieniu wpływu naprężeń ściskających w jej płaszczyźnie. Współczynniki wyboczeniowe $(k)$ dla tak sprężyście zamocowanych i zmiennie obciążonych na długości płyt krytycznych zamieszczono w cyklu artykułów autora [31, 32, 33, 34, 35, 36, 37, 38, 39, 40, 41, 42]. W pracach tych uwzględniono wzdłużny rozkład naprężeń wg funkcji stałej, liniowej lub nieliniowej (wg paraboli 2. stopnia). Dla tak obliczonych naprężeń krytycznych wyznaczono „lokalną” nośność krytyczną przekroju, która ogranicza zakres ważności teorii prętów cienkościennych Własowa (o nieodkształcalnym konturze przekroju). Przekroje, w których (dla określonych proporcji geometrycznych) ścianki ściskane ulegają jednoczesnej utracie stateczności (pod danym rozkładem naprężeń), nazwano przekrojami ,zerowymi”. W ich przypadku nie występuje wzajemne sprężyste zamocowanie płyt sąsiednich i spełnione jest normowe założenie separacji przegubowo podpartych płyt składowych przekroju pręta.

Do wyznaczenia obliczeniowej nośności granicznej przekroju cienkościennego zastosowano metodę szerokości współpracującej przy następujących założeniach: a) względne smukłości płytowe wyznacza się dla naprężeń krytycznych poszczególnych płyt składowych, b) dla płyty krytycznej są to naprężenia z uwzględnieniem jej sprężystego zamocowania przeciw obrotowi oraz wzdłużnej zmienności naprężeń, c) dla płyty usztywniającej należy przyjąć na tej samej krawędzi podparcie przegubowe, d) warunki brzegowe na drugiej krawędzi przęsłowej płyty usztywniającej mają na ogół nieznaczny wpływ na wynik obliczeń, (konserwatywnie można tu również przyjąć podparcie przegubowe), e) w przypadku wspornikowej płyty usztywniającej, druga krawędź pozostaje swobodna (nie podparta), f) wpływ ewentualnej wzdłużnej zmienności naprężeń w płycie usztywniającej jest nieznaczny i można go pominąć, g) tak wyznaczone szerokości współpracujące ,składa się” z powrotem w przekrój efektywny i na jego podstawie wyznacza się obliczeniową nośność graniczną.

Zastosowanie w praktyce metody płyty krytycznej (CPM) pokazano na przykładach obliczeniowych. Wyniki obliczeń analitycznych porównano również z wybranymi badaniami eksperymentalnymi. Z porównania wartości zamieszczonych w tabeli 1 wynika, że dla większości zbadanych przypadków występuje bardzo dobra (0.9-1) lub co najmniej dobra (0.8-0.9) relacja pomiędzy nośnością graniczną przekroju wyznaczoną wg CPM ( $\left.M_{e f f}{ }^{c p}\right)$, a nośnością graniczną wyznaczoną eksperymentalnie $\left(M_{u l t}{ }^{e x}\right)$. W przypadku obliczeń wg EC3 zanotowano znacznie większą rozbieżność wyników.

Wykazano, że uwzględnienie sprężystego zamocowania płyty krytycznej oraz wzdłużnej zmienności naprężeń prowadzi do wierniejszego odwzorowania zachowania się elementu cienkościennego w inżynierskim modelu obliczeniowym. Pokazana w pracy metoda umożliwia „ręczne” (lub zapisane w arkuszach kalkulacyjnych) wyznaczenie „lokalnej” nośności krytycznej oraz obliczeniowej nośności granicznej przekrojów cienkościennych przy relatywnie niewielkim nakładzie pracy. Umożliwia to np. projektowanie wstępne oraz prostą weryfikację obliczeń MES. 